\title{
Sarcoidosis: immunopathogenetic concepts and their clinical application
}

\author{
J. Müller-Quernheim
}

\begin{abstract}
Sarcoidosis: immunopathogenetic concepts and their clinical application. J. MüllerQuernheim. CERS Journals Ltd 1998.

ABSTRACT: Our understanding of the immunopathogenesis of sarcoidosis has been advanced by studies of bronchoalveolar lavage cells. Activated macrophages and Tcells have been identified in different compartments of the sarcoid lung and the characteristics of the activation suggest that the cells become activated in the course of a normal immune response. The immune cells communicate via a cytokine network and the measuring of cytokine levels yields subgroups of sarcoidosis patients with different courses of the disease indicating different states of activation of the disease-mediating immune cells. The causative agent of sarcoidosis has not yet been identified; however, some of the described mechanisms can be clinically applied either to detect patients at risk of deterioration or to develop new therapeutic strategies. Using these approaches methotrexate, pentoxifylline and thalidomide have been identified as drugs which effectively suppress sarcoid inflammation and the serum level of soluble interleukin-2 receptors has been delineated to be a serum marker of sarcoid inflammation. Furthermore, analysing the pulmonary cytokine network in sarcoidosis will yield new staging parameters possibly supplying prognostic information and guiding therapeutic intervention.
\end{abstract}

Eur Respir J 1998; 12: 716-738.

Sarcoidosis is a multiorgan disorder of unknown origin, characterized in the affected organs by T-lymphocytemononuclear phagocyte infiltration, granuloma formation and distortion of the normal microarchitecture [1]. The lung is the most commonly involved organ and studies with lung inflammatory cells from the lower respiratory tract recovered by bronchoalveolar lavage (BAL) and from other sites of the body have revealed concepts about the immunopathogenesis of the disease. Although the aetiology is still unknown, these concepts can be clinically exploited and this review will focus on the immunopathogenic concepts which have yielded new parameters to gauge the inflammatory activity of the disease and the effectiveness of new and established treatment protocols. An overview of the clinical features will be given, but for a more de-tailed clinical review of the extrathoracic manifestations the reader is referred to the literature [1].

The first article describing pulmonary alveolar lavage as a method for harvesting large numbers of macrophages from the rabbit lung was not published until 1961 by MүrVIK et al. [2]. With the introduction of the fibreoptic bronchoscope into clinical medicine by S. Ikeda, bronchoalveolar lavage has become widely used for clinical investigations [3]. The observation of characteristic changes in the cytology of BAL in interstitial lung diseases, first reported by HunNINGAKE and CRYSTAL [4] in 1981, gave rise to a large number of detailed investigations of pulmonary immunology in health and disease. The findings ob-tained by various researchers over the last 25 yrs form the basis of the concepts of immunopathogenesis of sarcoidosis discussed below.
Correspondence: J. Müller-Quernheim Medical Hospital

Research Centre Borstel

Parkallee 35

D-23845 Borstel

Germany

Fax: 494537188313

Keywords: Alveolar macrophage

cytokines

prednisolone

sarcoidosis

T-lymphocyte

Received: April 241998

Accepted May 61998

Supported by grants from the Deutsche Forschungsgemeinschaft (Mu 962/3-2 and Mu 962/5-2).

\section{Epidemiology}

Since many individuals with sarcoidosis are asymptomatic, estimates of the incidence rates and prevalence figures depend mainly on the way in which epidemiological data are generated. In Europe, sarcoidosis is the most frequently observed interstitial lung disease of unknown aetiology. The prevalence rates range from 64 patients per 100,000 population in Sweden to 9 per 100,000 population in Italy with intermediate numbers observed in Denmark (53 per 100,000), Germany (43), Ireland (40), Norway (27), The Netherlands (22), the UK (20), Switzerland (16) and France (10). The prevalence for the Caucasian population of North America is 3 and for AfroAmericans 47 per 100,000 [5]. Sarcoidosis is found in all races, affecting slightly more females than males. Most commonly, it manifests in adults aged $20-45$ yrs, although all ages can be affected.

Differences in the pattern of organ involvement and the severity of the disease have been observed according to race and ethnic background. Erythema nodosum associated with acute disease and good prognosis is most frequently seen in young Caucasians, as originally described by LÖFGREN [6]. Lupus pernio and other cutaneous manifestations of sarcoidosis, considered to be stigmata of chronic disease [7], appear more frequently in African-Americans than in Caucasians [8].

Only rough estimates of the mortality rates of untreated sarcoidosis are available. If untreated it is associated with a mortality rate of $\sim 5 \%$. In an epidemiological study from Denmark with a median follow-up of 27 yrs, an excess 
mortality from sarcoidosis and sarcoidosis-related diseases was perceived in the first $20 \mathrm{yrs}$ in patients with advanced radiological findings and deteriorated lung function. Although the mortality of the sarcoid cohort was higher than that of the general population the difference was not statistically significant $[9,10]$. This number may differ in other ethnic groups $[11,12]$ or cohorts with increased frequencies of certain manifestations, such as cutaneous sarcoidosis $[13,14]$.

\section{Genetics}

Numerous reports on familial sarcoidosis, human leucocyte antigen (HLA) linkages and divergent prevalence rates and clinical appearances in different races indicate the existence of genes predisposing for sarcoidosis $[8,15-$ 18].

Recently, maps of markers that cover the entire murine and human genomes have enabled the chromosome localization of many genes that predispose to autoimmunity in humans and animal models (reviewed in [19]). Using highly polymorphic markers in a family study of Crohn's disease a susceptibility locus was mapped to a region on chromosome 16 [20]. For sarcoidosis these studies are still in their infancy [21]. Many autoimmune or immunerelated diseases cluster in families and the degree of familial clustering of diseases can be estimated from the ratio between the risk of siblings suffering from a given disease and the population prevalence. If the sibling's risk is equal to the general prevalence familial clustering is not observed and the ratio $\left(\lambda_{\mathrm{s}}\right)$ is close to 1.0. When the siblings are at a greater risk of developing a given disease $\lambda_{\mathrm{s}}$ exceeds 1.0. For the diseases shown in table $1, \lambda_{\mathrm{s}}$ is greatly elevated. This is true for nongranulomatous diseases and granulomatous diseases such as Crohn's disease and primary biliary cirrhosis, which share some immunological features with sarcoidosis. The clustering of diseases in families is caused by genetic factors, environmental factors, or both. The $\lambda_{\mathrm{s}}$ for the major histocompatibility complex (MHC) is available for some diseases. If the overall $\lambda_{\mathrm{s}}$ equalled the MHC $\lambda_{\mathrm{s}}$ this would imply that only one MHC gene accounts for the clustering. It is evident from table 1 that in all diseases where data are available $\lambda_{\mathrm{s}}$ greatly exceeds MHC $\lambda_{s}$, implying that the linkage of the MHC region cannot entirely account for the clustering. In Crohn's disease $\left(\lambda_{\mathrm{s}}=20, \mathrm{MHC} \lambda_{\mathrm{s}}=1.3\right)$ genome scans have identified a susceptibility locus outside the MHC on chromosome 16 [20]. Interestingly, the gene of Blau's syndrome (familial granulomatosis), an autosomal, dominantly Mendelianinherited disease characterized by multiorgan inflammation with granulomatous arthritis, skin rash and uveitis, has been mapped to the same region [27].

Estimating $\lambda_{\mathrm{s}}$ of sarcoidosis, from the numbers available for Germany $[16,28]$, yields a range from 8 to 20.0 and points very strongly to the existence of predisposing genes (table 1). For berylliosis, an occupational disease clinically indistinguishable from sarcoidosis, an association between this disease and the presence of a glutamine residue at position 69 (Glu69+) of the $\beta 1$-chain of the HLA-DP molecule has been identified [29]. A study analysing this locus in a series of 24 patients with sarcoidosis failed to demonstrate an association [30] but two others $[31,32]$ examining 41 and 38 patients, respectively, succeeded in showing an association. The author's group analysed 17 familial clusters for the presence of Glu69+ and found an over-representation; however, this allele was not shared by any of three sib triplets included in this study [33]. These discordant findings of over-representation of distinct HLA genes in sarcoidosis patients and the lack of linkage in sarcoidosis families might be caused by a more complex genetic background, as indicated by ethnic differences in the frequency of the genes in question [31]. Heterogeneity of the disorder itself and polygenic triggering of its course might also be involved.

On chromosome 17 another gene polymorphism, a 300 base-pair (bp) deletion/insertion polymorphism in exon 16 of the angiotensin-converting enzyme (ACE) gene, is thought to be associated with sarcoidosis [34-36]. In a Japanese study an excess of genotypes ID or DD was observed in female patients [34], but in another investigation from Japan there were no significant differences in the I/D ratio and the genotype distribution between the patients with sarcoidosis and controls [37]. The testing of different models of inheritance in our deoxyribonucleic acid (DNA) bank of familial sarcoidosis clusters revealed no cosegregation of the ACE gene with familial sarcoidosis [38], giving further support to the notion that the ACE polymorphism is not responsible for the development of sarcoidosis [37]. However, an over-representation of the allele with the insertion was observed in both family members with and without sarcoidosis, which may indicate a participation of this allele in a multifactorial disease process. The I/ D polymorphism does not alter the ACE protein structure

\begin{tabular}{|c|c|c|c|c|c|}
\hline Disease & $\begin{array}{c}\text { Population } \\
\text { frequency } \\
\%\end{array}$ & $\begin{array}{c}\text { Sibling } \\
\text { risk } \\
\%\end{array}$ & $\lambda_{\mathrm{s}}$ & $\operatorname{MHC} \lambda_{\mathrm{s}}$ & Reference \\
\hline Psoriasis & 2.8 & 17 & 6 & & {$[22]$} \\
\hline Rheumatoid arthritis & 1.0 & 8 & 8 & 1.6 & [23] \\
\hline Ulcerative colitis & 0.1 & 1.2 & 12 & 8.3 & [24] \\
\hline Type 1 diabetes & 0.4 & 6 & 15 & 2.4 & [25] \\
\hline SLE & 0.1 & 2 & 20 & & [26] \\
\hline Multiple sclerosis & 0.1 & 2 & 20 & 2.4 & [25] \\
\hline Crohn's disease & 0.06 & 1.2 & 20 & 1.3 & [24] \\
\hline Primary biliary cirrhosis & 0.008 & 0.8 & 100 & & [26] \\
\hline Sarcoidosis & 0.04 & $0.3-0.8$ & $8-20$ & & \\
\hline
\end{tabular}

$\lambda_{\mathrm{s}}$ : ratio between the risk of siblings suffering from a given disease and the population prevalence; MHC: major histocompatibility complex; SLE: systemic lupus erythematosus. (Modified from [19].) 
but it influences the serum ACE level. Compared with heterozygote individuals, the DD genotype is associated with higher and the II genotype with lower ACE levels. ACE serum levels are clinically employed to gauge the granuloma burden of the body [39] and in the future the use of genotype-corrected normal ranges will improve the low sensitivity of this marker $[36,40]$.

\section{Aetiology}

Many agents have been implicated as possibly providing the stimuli that elicit the granulomatous response of sarcoidosis. As early as 1905, C. Boeck described sarcoidosis as "a bacillary infectious disease, which is either identical to tuberculosis or closely related to it"; however, proof of this hypothesis remains elusive and there is an ongoing discussion about this question. Besides mycobacteria and inorganic agents, even viruses, e.g. herpesviruses, seem to be capable of inducing sarcoid-type granulomas [41].

High titres of antibodies against lymphotropic DNA viruses (Epstein-Barr virus (EBV), human herpesvirus (HHV), cytomegalovirus), parainfluenza, rubella and mycobacteriophages have been found in patients with sarcoidosis. Using the polymerase chain reaction (PCR) viral DNA can be identified in tissues from varying numbers of sarcoidosis patients. Adenovirus DNA was found in a small percentage of patients with sarcoidosis [42] and HHV-8 DNA sequences were detected in significantly higher proportions of sarcoid than of nonsarcoid tissue from lung, lymph nodes, skin and oral tissues [43]. Whether these associations are causal or not and whether they point to a general association between viruses and granuloma require further studies. HHV-8 DNA is found in Kaposi's sarcoma and in the blood and other body fluids of groups at high risk of Kaposi's sarcoma [44, 45]. Studies using better techniques to seek viral sequences in blood [46], tissues [47] or body fluids other than blood [48] and studies identifying serum antibodies to $\mathrm{HHV}$-specific peptides $[49,50]$ indicate that HHV-8 infection in populations not at risk of Kaposi's sarcoma may be more prevalent than previously thought. In line with this notion is the observation of Di AlBERTI et al. [51], who identified different HHV8 sequences from different body sites of persons infected with human immunodeficiency virus, which suggests multiple infections with HHV in these patients that are possibly associated with disease processes. However, at present a viral cause of sarcoidosis has not been substantiated by viral cultures or unequivocal tissue analysis.

Using methods of histology, bacterial cultures and molecular biology the presence of acid-fast rods, mycobacterial DNA and mycobacterial ribonucleic acid (RNA) has been demonstrated in sarcoidosis [51-56]. However, other investigators have not been able to reproduce these findings, and based on the assumption that in a range of $2,500-10^{6}$ host cells of established lesions more than six to 15 organisms are required to play a pathogenic role, it has been concluded that Mycobacterium tuberculosis or other mycobacteria are not involved in sarcoidosis [5759]. An interesting point is the detection of $16 \mathrm{~S}$ ribosomal RNA (rRNA) sequences of as yet unidentified mycobacteria in sarcoid lymphoid and skin tissue by Di AlBERTI et al. [43] who could not find DNA sequences of M. tuberculo- sis in these samples. VorkuRa et al. [60] used a sequence capture PCR, which is about 100-fold more sensitive than conventional PCR protocols, to seek the mycobacterial insertion segment 6110 and the mycobacterial DR region. Although in this study $M$. tuberculosis was detected in samples of paucibacillary tuberculosis, this approach did not obtain positive results for sarcoidosis, which supports previous studies suggesting that $M$. tuberculosis does not play a pathogenic role in sarcoidosis in most patients. Owing to the sequences of the chosen primers VORKURA et al. [60] could not detect the sequences reported by $\mathrm{DI}_{\mathrm{I}}$ AlBERTI et al. [43]. Thus, these studies support each other in the conclusion that $M$. tuberculosis cannot be found in sarcoid tissues. The relevance of the yet undefined mycobacteria needs to be determined.

Epidemiological data and similarities with other infectious diseases support the hypothesis that sarcoidosis is induced by an infectious organism. Seasonal clusterings of sarcoidosis in the months of June and July [61], time and space clusters $[62,63]$, an increased incidence in health workers [64] and the transmission of sarcoidosis by transplants [65] have been observed and further support the hypothesis of transmissible sarcoid-inducing agents. For example, Borrelia burgdorferi has recently been proposed as a possible cause of sarcoidosis [66, 67], although data obtained by the author's group do not support this hypothesis [68]. Furthermore, a recent report has demonstrated the presence of antibodies against Chlamydia pneumoniae in 20 out of 24 sera from patients with sarcoidosis [69]. However, in other study populations DNA of $C$. pneumoniae could not be detected in tissue samples of sarcoid lung [70], and patients with sarcoidosis did not exert an increased seroprevalence of antibodies against Chlamydia spp. [63]. In most countries, including Germany, there is a high anti-Chlamydia seroprevalence and preliminary results from the author's laboratory do not show an elevated anti-Chlamydia seroprevalence in sarcoidosis. Therefore, the presence of Chlamydia spp. in patients with sarcoidosis should be evaluated with scrutiny. The presence of virus- and bacteria-specific antibodies in high titres might reflect generalized B-cell activation in sarcoidosis and does not necessarily indicate a causal relationship.

In this context an epidemiological study from Denmark is of interest, which raises a dual infection hypothesis in combination with a genetic susceptibility hypothesis for multiple sclerosis. Infection with a hypothetical, widespread "multiple sclerosis retrovirus" is a prerequisite for the development of multiple sclerosis, but the disease develops only in individuals who were infected with EBV around puberty or later in life and are genetically susceptible [71]. Owing to its clinical heterogeneity such a hypothesis is difficult to test for sarcoidosis.

Most interestingly, there are case reports of sarcoidosis patients who suffered from a relapse of sarcoidosis in a transplanted lung despite receiving immunosuppressive therapy [72-74]. Conversely, in two out of four cases patients receiving a lung or other organs from a donor who had a spontaneous remission of sarcoidosis in the past were observed to develop sarcoid-like lesions without suffering from sarcoidosis [73]. Others report the transmission of sarcoidosis by cardiac transplant [65]. These observations suggest that the aetiological agent hides within the lung and/or other compartments of the body. In view of the studies described above and the fact that only a few years 
ago the infectious organisms of cat-scratch disease (Bartonella henselae) [75] and Whipple's disease (Tropheryma whippelii) [76], two granulomatous disorders of hitherto unknown aetiology were identified, it seems feasible that one or several infectious agents inducing sarcoidosis might be identified in the future.

Based on the hypothesis that sarcoidosis might be an infectious disease, several investigators have attempted to develop skin tests similar to that of Mendel and Mantoux for tuberculosis. WiLLiams and Nickerson [77] reported in 1935 that within $24 \mathrm{~h}$ the intradermal inoculation of a preparation of sarcoid tissue into four patients with suspected sarcoidosis and four normal control subjects yielded firm red papules in the sarcoid group. KveIm [78], a dermatologist from the Christiania Hospital in Oslo, subsequently made the important observation that these papules consist of sarcoid tissue. CHASE [79] proposed a standardized procedure for the preparation of the test reagent still in use today. Siltzbach [80] performed comprehensive studies establishing the practicability of the test as a diagnostic tool and the Kveim-Siltzbach test is still applied in a number of countries for the diagnosis of sarcoidosis. So far, the nature of the Kveim reagent remains obscure. Denaturing experiments have revealed that the active, granulomainducing principle should consist of a protein and depends on its three-dimensional structure [81].

T-cells from sarcoid patients do not proliferate after stimulation with Kveim reagent [82] and in spite of many attempts it has not been possible to develop an in vitro test for clinical routine purposes [83]. Employing different immunoelectrophoretic methods, ReuTGen et al. [84] demonstrated 3-11 precipitation lines in the Kveim reagent. Immunohistochemical stainings with antisera or monoclonal antibodies against Kveim reagent showed reactivity to epitheloid cells in sarcoid granulomas and, to a lesser extent, in tuberculoid granulomas $[84,85]$. Additional studies revealed that an anti-Kveim reagent monoclonal antibody recognizes both epithelial cells and giant cells from granulomas from patients with summer-type hypersensitivity pneumonitis, Crohn's disease, foreign body granuloma and Wegener's granulomatosis. These data show that at least one fraction of this preparation consists of proteins related to granuloma development in general and are not specific to sarcoidosis.

In an ongoing study in the author's laboratory bacterial or mycobacterial DNA was searched for in the Kveim reagent. DNA coding for the 16S rRNA, which is an essential part of the bacterial ribosome, could not be detected in Kveim reagent or a sarcoid spleen. Thus, the negative results obtained do not support the hypothesis that the cutaneous granuloma at the site of a positive Kveim reaction are caused by bacteria [86]. However, the possibility that bacterial products such as superantigens or membrane fragments [87] induce these reactions cannot be excluded. Numerous immunobiological studies, especially those dealing with lymphocytes, have shown that most of the immune characteristics of the sarcoid reaction are shared with the normal immune response, supporting the hypothesis of an infectious aetiology of sarcoidosis [88, 89]. The fact that bacterial DNA cannot consistently be found in Kveim reagent or in sarcoid lesions suggests that, if an infectious aetiology of sarcoidosis exists at all, bacteria or viruses may trigger the sarcoid response, which may be maintained by undegradable products of these species or by autoaggressive or cross-reacting host mechanisms after the causative agent has been cleared, as has been demonstrated for infectious arthritis [87]. This notion is further supported by studies indicating that the active principle of the Kveim reagent is of a proteinous nature $[81,90]$.

Exposure to inorganic or organic dusts can cause diseases that are clinically and histologically indistinguishable from sarcoidosis. The most prominent example is berylliosis, for which a genetically defined susceptibility has been identified. Those individuals with a glutamate instead of a lysine in position 69 of the HLA-DPB1 are prone to develop beryllium sensitization and eventually, if exposed, beryllium disease [29]. In firefighters and people exposed to photocopier toner dust, clusters of sarcoidosis or a disease indistinguishable from sarcoidosis have been reported $[63,91]$. Noninfectious microbial products are capable of inducing autoimmune diseases by an interleukin (IL)12-dependent pathway. The cytokine-modulating properties of these products convert quiescent autoaggressive T-cells in effector cells capable of transferring immunopathological mechanisms [92]. In line with this observation is the finding that exposure to a respirable bioaerosol containing endotoxin and microbial contaminants during work as a lifeguard at an indoor pool may induce a granulomatous pneumonitis identical to sarcoidosis [1]. Thus, the exposure of susceptible individuals to minute amounts of both organic and inorganic agents may cause diseases indistinguishable from sarcoidosis, lending further support to the hypothesis of an environmental cofactor.

\section{Clinical features}

Although the onset of the disease is usually insidious and discovered in asymptomatic individuals by routine chest radiography or heralded by constitutional complaints, it will occasionally manifest itself as a medical emergency. Involvement of the eye, heart or central nervous system or the development of hypercalcaemia may require immediate action. More than $90 \%$ of sarcoid patients will eventually develop pulmonary abnormalities easily recognizable on chest radiography or by tests of pulmonary function [93].

The chest radiograph is rarely normal; most commonly it reveals bilateral hilar adenopathy and/or diffuse reticulonodular infiltrates in the parenchyma. Lung function tests usually reveal a decrease in lung volumes (vital capacity and total lung capacity), a reduced diffusing capacity and a mildly reduced arterial oxygen tension that may diminish further with exercise. In general, the ratio of forced expiratory volume in one second to vital capacity is normal [94], although sensitive tests reveal airflow limitation [95] and $\sim 20 \%$ of the patients present with unspecific bronchial hyperreactivity $[96,97]$.

An evaluation of transbronchial or open lung biopsies of patients in the early stages of sarcoidosis provides an insight into why the patients suffer from the clinical findings outlined above. The typical findings are those of noncaseating granulomas within the alveolar, bronchial and vascular walls. These granulomas are diffusely scattered throughout the lung parenchyma. In contrast to the granulomas seen in hypersensitivity pneumonitis, the granulomas of sarcoidosis are well-formed, compact aggregates. They are usually of varying age, ranging from highly 
cellular lesions to collections with diminishing cellularity, some fibrosis and progressive hyalinization. Two characteristic zones can be seen in a typical, well-developed sarcoid granuloma: 1) a central zone or follicle which is tightly packed with cells, composed primarily of macrophages, multinucleated giant cells and epitheloid cells; and 2) a peripheral zone consisting of a collar of loosely arranged lymphocytes, monocytes and fibroblasts [98]. Although many microscopic features may suggest sarcoidosis, the epitheloid granulomas, especially in their earlier stages, are indistinguishable from those of other idiopathic granulomatous disorders or even granulomatous disorders of known origin, such as berylliosis, tuberculosis or hypersensitivity pneumonitis.

Thus, sarcoidosis is best defined in histopathological terms as "a disease characterized by the presence in all of the several affected organs and tissues of noncaseating epitheloid-cell granulomas, proceeding either to resolution or to conversion into hyaline connective tissue" [99]. The clinical diagnosis, however, can only be supported by typical histopathological findings. Pathogenomonic criteria or a diagnostic "gold standard" are absent. Most authorities thus include several clinical, radiological, immunological and histological features in their diagnostic criteria since other disease processes can simulate sarcoidosis in many ways. Occasionally, all of these features may suggest the diagnosis of sarcoidosis in patients later proven to have other diseases [100-102]. Therefore, rigorous efforts have to be made to exclude alternative diagnoses, e.g. tuberculosis, lymphoma and berylliosis [100-105] and patients diagnosed as suffering from sarcoidosis must be regularly subjected to review and further testing [106].

Most patients with diagnosed sarcoidosis will undergo clinical and radiological resolution of the disease over a period ranging from several months to a few years [107]. A few develop a progressive form of the disease which may result in death [108]. In those patients undergoing resolution, subsequent biopsy or material examined at necropsy may reveal changes ranging from complete resolution with no scarring to focal pulmonary scars without evidence of granuloma formation. The fate of the sarcoid granuloma is morphologically well documented. It may appear fresh for months to years, however, the granuloma ultimately resolves, leaving no morphological changes, or undergoes an obliterative fibrosis. The fibrosis starts as a rim of collagen around the granuloma and proceeds in a centripetal fashion until the entire structure is replaced by fibrous tissue. The late stage of sarcoidosis is characterized by an extensive, patchy pulmonary fibrosis and a hypertrophy of pulmonary arteries [1, 98, 99].

The natural course of sarcoidosis is unpredictable in an individual patient. For instance, patients with advanced pulmonary infiltrates and splenomegaly may have spontaneous recovery, whereas others with asymptomatic hilar adenopathy may develop severe disease. Extensive clinical and epidemiological studies performed since 1950 emphasize the generally favourable outcome of sarcoidosis. About $70 \%$ of the patients presenting with hilar adenopathy alone (i.e. radiographic Type I) have a spontaneous resolution. In patients presenting with diffuse pulmonary infiltrates with (Type II) or without (Type III) hilar adenopathy this figure is reduced to about $50 \%$. A $40 \%$ mortality rate has been observed in those who pre- sented with radiographic signs of fibrosis. In general, the more severe the clinical findings at the time of diagnosis and the more organ systems are affected by the disease, the more frequently adverse courses have been observed. Cutaneous sarcoid frequently indicates chronic and disseminated involvement and the prognosis, in general, is poor in patients with advanced skin lesions [10, 108, 109].

\section{Immunopathogenesis}

\section{Alveolar macrophages}

A number of cytokines chemotactic for monocytes is produced by alveolar cells in the course of inflammatory reactions of sarcoidosis and other interstitial lung diseases [110-112], leading to a considerable increase in lavage cellularity with an expansion of the absolute number of alveolar macrophages. The percentage of alveolar macrophages with monocytic appearance is elevated in sarcoidosis and idiopathic pulmonary fibrosis, suggesting a recent immigration of monocytic precursors of alveolar macrophages from the blood [113]. However, those markers characteristic for a monocytic immunophenotype can be acquired by alveolar macrophages in the course of activation [114] and evidence for a local proliferation of alveolar macrophages has been obtained for sarcoidosis [115]. Thus, the question of monocyte immigration has not yet been settled.

The activated state of these cells has been demonstrated by their spontaneous ex vivo cytokine production. IL-1, tumour necrosis factor (TNF)- $\alpha$, IL-6, macrophage inflammatory protein-1 (MIP-1), monocyte chemotactic protein-1 (MCP-1) and "regulated on activation, normal T-cell expressed and secreted" (RANTES) have been identified as being released by alveolar macrophages in the course of sarcoidosis [111, 116-121]. This activation of the cells of the monocyte/macrophage lineage is compartmentalized, i.e. alveolar macrophages release these mediators spontaneously, whereas the corresponding cells of the peripheral blood are quiescent. Kinetic studies on the transcription of the TNF- $\alpha$ gene revealed that maximal messenger RNA (mRNA) transcription is reached within $2 \mathrm{~h}$ after stimulation. Cytoplasmic TNF- $\alpha$ was detected as early as $1 \mathrm{~h}$ after stimulation, increasing over the next $2 \mathrm{~h}$ to be followed by a decline [122]. Similar experiments with sarcoid alveolar macrophages revealed the transcription of the TNF- $\alpha$ gene at the time of BAL and its downregulation during the next $24 \mathrm{~h}$ in cell culture [118]. Thus, the heightened spontaneous TNF- $\alpha$ release seen in active sarcoidosis is a consequence of an in vivo activation step just prior to the removal of the cells from the lung, indicating that the eliciting agent resides in the lower respiratory tract. In addition, a priming for an increased release of leukotriene B4 was observed in sarcoid alveolar macrophages, which indicates a different response of these cells to stimulating agents [123].

TNF- $\alpha$, in particular is released at high concentrations; however, a corresponding cachectin effect is absent in most patients, giving rise to the hypothesis that TNF- $\alpha$ binding or -neutralizing proteins or counteracting cytokines are simultaneously released [124]. Soluble TNF receptors (sTNF-R) may be capable of counteracting TNF- $\alpha$ effects 
[125]. In many pulmonary disorders including sarcoidosis elevated levels of sTNF-R are found in the BAL fluid [126] and increases in the plasma levels of these molecules correlating with disease activity have been observed [127]. Preliminary results obtained by the author's group demonstrate the presence of increased sTNF-R serum levels correlating with alveolar macrophage TNF- $\alpha$ release and this might, therefore, play a role in dampening the cachectin effects of TNF- $\alpha$, as observed in a number of diseases [128].

The accessory capabilities of sarcoid alveolar macrophages have been found to be increased, as measured by mixed lymphocyte reactions and antigen presentation $[129,130]$. The interpretation of these experiments has, however, been complicated by possible stimulations via minor histocompatibility antigens or by intrinsic activities of autologous sarcoid T-cells present in the test. In a different cell-culture system using a method insensitive to histoincompatibilities, sarcoid alveolar macrophages were shown to express increased accessory functions mediated by adhesion molecules, e.g. CD80 [131]. This increased accessory function could only be demonstrated in patients with active sarcoidosis, and not in patients with inactive sarcoidosis or controls. In addition, alveolar macrophages from patients with other granulomatous (tuberculosis, hypersensitivity pneumonitis and Wegener's disease) and nongranulomatous lung diseases also disclosed increased accessory function of alveolar macrophages, suggesting that this increase is an unspecific stimulation marker of these cells. One mechanism for the induction of CD80 and CD86 is the interaction of MHC class II molecules with the T-cell receptor [132]. Furthermore, increased accessory function can be induced by T-cell-derived cytokines such as IL-2 [133] or interferon-gamma (IFN- $\gamma)$ (G. Zissel, unpublished observations). This, again, indicates that $\mathrm{T}$ cell activation, possibly by a nominal antigen, is involved in the pathogenesis of sarcoidosis. It is hypothesized that costimulation by CD80 and CD86 influences the differentiation of T-helper (Th)1/Th2 cells as CD80 costimulation leads to more of an activation of Th1 cells, whereas CD86 costimulation induces only Th2 cells [134]. Therefore, increased accessory function of alveolar macrophages influences the composition of alveolar T-cells and the cytokine pattern in the lower respiratory tract.

\section{T-cells}

Sarcoidosis is associated with an increase in the number of alveolar T-cells and a shift to an increase in CD4+ cells within these cells can be seen. In some cases of sarcoidosis $>50 \%$ of T-cells with a CD4/CD8 ratio $>10$ which exhibit markers of activation, such as increased HLA-DR, very late activation antigen-1 (VLA-1), and IL2 receptor expression and capping of the T-cell antigen receptor (TCR), can be observed [4, 135-138]. The Tcells of the granuloma exhibit a layer-like distribution, with CD4+ cells expressing an abundance of activation markers predominantly in the inner area and an accumulation of CD8+ cells with smaller numbers of those markers in the outer area $[139,140]$.

Alveolar T-cells have been found to release in vitro IL-2 without stimulation in tissue culture [141, 142]. In spite of the systemic nature of the disease only the alveolar T-cells and not those of the peripheral blood spontaneously secreted IL-2. Interestingly, the regulation of the transcription of the IL-2 gene appeared to be normal, indicating a stimulation of the cells in a physiological fashion [88, 137]. This view is supported by the finding of Du Bors et al. [138], who demonstrated a capping of the TCR of alveolar Tcells in sarcoidosis, suggesting a recent activation of the cells via this complex. These two phenomena can only be observed in cells of the BAL, indicating that the eliciting agent resides in the lung or that activated cells are attracted to the lung. A similar activation can be assumed for the T-cells of the granuloma since they contain mRNA for IL-2, IL-6 and IFN- $\gamma$, which is in line with the detection of these cytokines in lymph node extracts of patients with sarcoidosis [143, 144].

The enumeration of IL-2 receptor (IL-2R)-positive Tcells was considered to be one approach by which to estimate the number of activated alveolar T-cells. Only a moderate increase in IL-2R+ T-cells, with only a few cells going through the S-phase of the cell cycle, was observed $[88,137,145]$, suggesting the presence of a small number of activated cells in the alveolar space or a dysregulation in the expression of the IL-2R. Results obtained by an in vitro study with sarcoid T-cells excluded the latter possibility [137]. However, the milieu of the lower respiratory tract generated by type II epithelial cells modulates the reactivity of the T-cells. In the presence of type II epithelial cells, activated T-cells are arrested and do not progress further in the cell cycle. This blockade is reversed when the cells leave this suppressive milieu, e.g. after migration to the lymph node [146]. In fact, in sarcoid lymph nodes an exaggerated lymphocyte proliferation can be observed [147].

Studies with the Kveim reagent revealed that its activity resides within the membrane fragments of alveolar macrophages, thus corroborating the hypothesis that a sarcoid-specific protein is presented by these cells [148]. However, an antigen has not yet been identified and, therefore, several researchers have analysed the usage of the TCR V-region and C-region repertoire in sarcoidosis. The underlying assumption of this approach is that T-cell clones are activated and expanded by the postulated "sarcoid-antigen", resulting in an increased usage of certain Vregion families of the TCR, which can be evaluated by staining or by identifying the V-region mRNA in these Tlymphocytes.

MOLLER et al. [149] were the first to demonstrate a bias towards an increased usage of the $\mathrm{V}_{\beta} 8$ region of the TCR in sarcoidosis peripheral blood and BAL T-lymphocytes, suggesting that $\mathrm{T}$-cells accumulate as a result of external selective pressure, rather than in a random polyclonal fashion or by clonal expansion of one or a few T-cell clones. This observation has been extended to show restricted usage of TCR $V_{\alpha}$ [150], $V_{\beta}$ [151] and $C_{\beta}$-chains [152] in BAL and lung parenchyma [153]. However, no clear distinction between polyclonal and oligoclonal T-cell proliferation in sarcoidosis could be made. Other technical approaches have demonstrated an increased clonality in BAL cells without detecting preferred V-region families, leading to the assumption that the major source of T-cells is a polyclonal unspecific accumulation accompanied by a clonal expansion, contributing about $10 \%$ of the T-cells $[154,155]$. In these studies sarcoidosis was not observed to select certain $\mathrm{V}_{\beta}$-families of the TCR in the detected 
clones, thus supporting the hypothesis of an unspecific stimulus. However, KLEIN et al. [89] demonstrated an increased percentage of $\mathrm{V}_{\beta} 2, \mathrm{~V}_{\beta} 3, \mathrm{~V}_{\beta} 6$ and $\mathrm{V}_{\beta} 8$ families in intradermal lesions of Kveim skin-tests compared with peripheral blood and that this increase was oligoclonal. These findings are consistent with an antigen-driven T-cell activation and the limited clonality of T-cells could also be demonstrated in sarcoid lung T-cells by analysing the nucleotide sequence of the TCR [156]. The association of this oligoclonality with the course of the disease is demonstrated by the fact that oligoclonality decreases after clinical improvement of the disease either by spontaneous remission or after corticoid therapy [156]. In addition, in some cases an amino acid motif in the $\mathrm{V}_{\beta} / \mathrm{J}_{\beta}$-region of the TCR could be identified which had not been described before and might therefore be typical for sarcoidosis [151]. These data suggest that, at least in part, the immune response is elicited by a "sarcoid antigen". In view of the absence of a clonal expansion of one distinct $V_{\beta}$-family the hypothesis of a superantigen as a possible causative agent of sarcoidosis can be excluded.

FORMAN et al. [151] studied the TCR $\mathrm{V}_{\beta}$ distribution in normal lung and blood by quantitative PCR analysis and observed similar distributions in both compartments and that this distribution is relatively stable with only limited changes in a healthy individual over time [157]. In line with this finding are the results of BURASTERO et al. [158] who analysed the TCR $\mathrm{V}_{\beta}$ pattern of T-cell clones generated from BAL and peripheral blood and found no significant difference in the TCR $V_{\beta}$ usage in these two body compartments. Thus, the analysis of the TCR $\mathrm{V}_{\beta}$ pattern of T-cell clones from sarcoidosis patients will provide insight into immune mechanisms taking place in body compartments other than blood or BAL. In a recent study in the author's laboratory T-cell clones were generated from lung parenchyma, BAL and peripheral blood of patients with sarcoidosis. The analysis of the TCR $\mathrm{V}_{\beta}$ pattern of these clones revealed a variability of $V_{\beta}$ family usage of the T-cells in the analysed compartments (fig. 1) and the most prominent changes were observed in the CD4+ cells of BAL. Most interestingly, the TCR $V_{\beta}$ pattern of the compartments BAL and lung parenchyma did not show iden-tical skewing, but exhibited different clonal expansions demonstrating substantial differences in the composition of the T-cell population of these neighbouring compartments [153]. The rise and fall of oligoclonality of BAL CD4+ cells can be observed in berylliosis [159] and that of CD8+ cells in hypersensitivity pneumonitis [161]. More-over, BAL T-cell oligoclonality vanished in patients with sarcoidosis or hypersensitivity pneumonitis after spontaneous resolution or after treatment of the respective dis-order [156, 160]. These observations in interstitial lung diseases of known origin suggest that the skewing of the TCR $V_{\beta}$ families in sarcoidosis is the result of an oligoclonal T-cell activation by a still elusive "sarcoid agent". GRUNEWALD et al. [161] sequenced the rearrangement of the $V_{\alpha} / J_{\alpha}$ gene segment of the TCR in sarcoidosis patients without identifying any preferences of V-region gene usage. Moreover, sequence differences of the rearranged gene segments did not result in changes of the amino acid sequence of the antigen-binding site of the TCR, which provides further evidence that in sarcoidosis T-cells be-come activated by a nominal antigen leading to an oligoclonal T-cell expansion.

In the past few years two functional distinct subsets of CD4+ T-cells have been described by their capacity to release a definite panel of cytokines, first in the mouse $[162,163]$ and later in the human system [164]. Th1 cells release IL-2, IFN- $\gamma$ and lymphotoxin and are related to cell-mediated immunity, while Th2 cells release IL-4, IL5, IL-10 and IL-13 and are related to B-cell help. Both lineages derive from naive Th0 cells, which are able to release the whole panel of cytokines and differentiate into either Th1 or Th2 cells after antigen stimulation, depending on antigen concentration, the affinity of the antigen to the MHC class II molecules and the nature of the antigen. In sarcoidosis, a spontaneous release of Th1 cytokines (IFN- $\gamma$ and IL-2) by BAL T-cells could be demonstrated
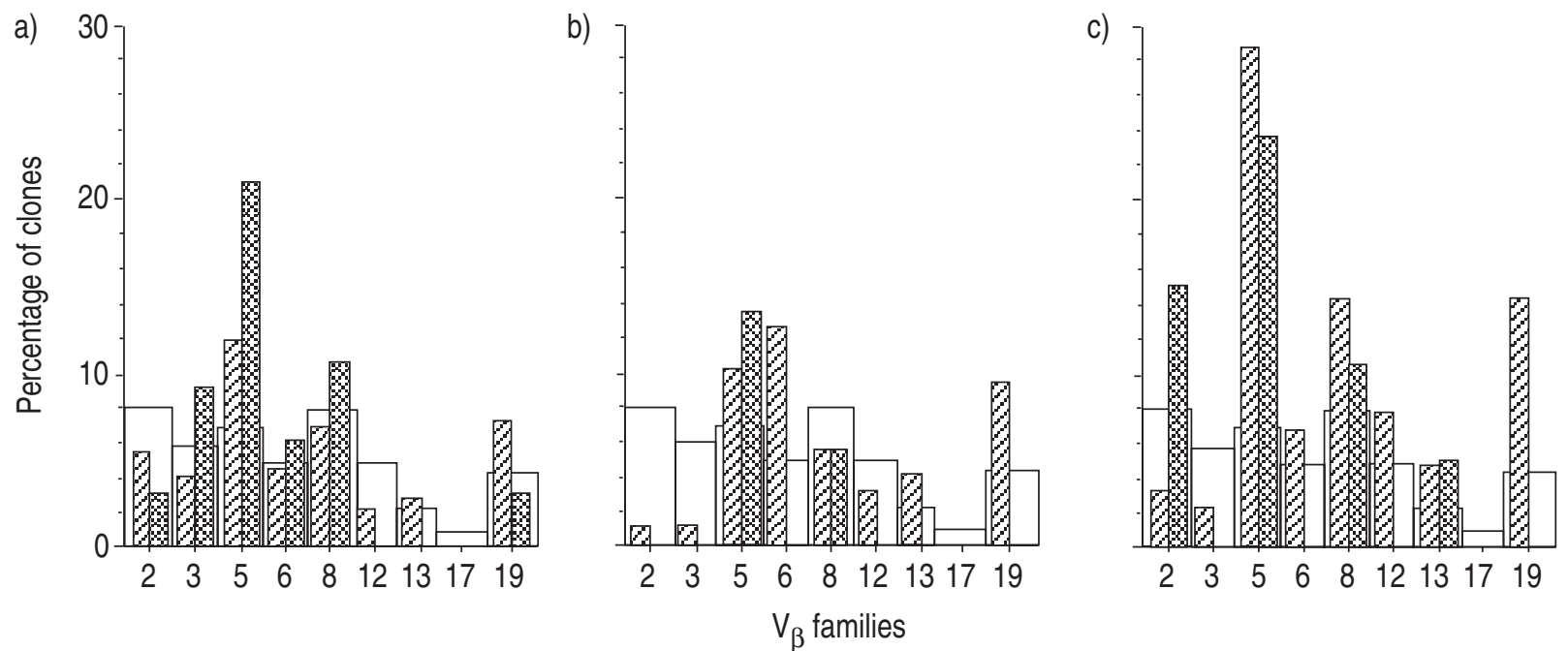

Fig. 1. - T-cell clones generated from different body compartments in patients with sarcoidosis ( $\angle$ ) and controls ( $\$$ ) ). The expected range of the $\mathrm{V}_{\beta}$ family is also shown $(\square)$. Clones were generated from: a) peripheral blood, b) transbronchial biopsy, and c) bronchoalveolar lavage. The variable region of the $\beta$-chain $\left(\mathrm{V}_{\beta}\right)$ usage of the T-cell antigen receptor (TCR) was analysed by enzyme-linked immunosorbent assay with antibodies against oligomorphic parts of the TCR characteristic for the different families and indicated as a percentage of all analysed clones. By analysing nine $\mathrm{V}_{\beta}$ families about $40 \%$ of the T-cell repertoire was screened. The $\mathrm{V}_{\beta}$ pattern indicates skewing in the sarcoid clones similar to that of antigenic disorders, supporting the notion of an antigen-driven selection of the TCR repertoire. (Modified from [153].) 
[141, 165], but not the release of Th2 cytokines [126, 166, 167]. Indeed, BäUMER et al. [168] demonstrated that T-cell clones derived from peripheral blood, BAL cells and lung parenchyma of sarcoid patients disclose the entire spectrum of cytokine patterns. Th2-like cells could be demonstrated in all three body compartments, including BAL. From this, one can assume that although Th2 cells are present, they are not activated or even suppressed, which may contribute to the immunopathogenesis by maintaining a cytokine imbalance in the lung. The importance of the cytokine balance for the development of a disease can be demonstrated by an asthma patient with improving asthma (a Th2 disease) during an attack of active sarcoidosis (a Th1 disease) [169].

In addition to the bias described in the usage of the $\alpha / \beta$ TCR, a bias in the use of the $\gamma / \delta$ TCR has been observed. In some sarcoidosis patients elevated numbers of $\gamma / \delta$ TCR positive blood and lavage lymphocytes have been reported [170-172]; a bias for the use of some $\mathrm{V}_{\delta}$-chain genes was identified and these cells exhibited signs of recent activation $[173,174]$. The observation of increased levels of circulating $\gamma / \delta$-T-cells has renewed interest in the potential role of mycobacteria in the aetiology of sarcoidosis. However, TAZI et al. [175] demonstrated that the majority of Tcells in lymph node granulomas and in Kveim granulomas of sarcoid patients are $\alpha / \beta$-T-cells.

The majority of the findings with regard to sarcoid Tcell response are characteristic of a T-cell-mediated response to antigen and are highly suggestive of the presence of a persistent, poorly degradable antigen or antigens. This concept is further supported by studies of autoimmune and chronic inflammatory diseases demonstrating a compartmentalized accumulation of T-cells with restricted $\mathrm{V}_{\beta}$ chain gene usage $[176,177]$.

\section{Granuloma}

Granuloma is a feature of many chronic interstitial lung diseases, e.g. sarcoidosis, hypersensitivity pneumonitis, berylliosis and histiocytosis X. An initial event triggering granuloma formation in diseases of known origin is the deposition of antigenic substances in the lung, as observed in tuberculosis and hypersensitivity pneumonitis. Interestingly, in berylliosis the triggering event seems to be the binding of beryllium to HLA molecules on the surface of the immune cells [178]. The immune system, however, recognizes peptides in the context of self on the surface of antigen-presenting cells and the sole binding of beryllium may not be a sufficiently stimulating event. Therefore, other triggers such as an altered cleavage of self-antigens, caused by a beryllium-induced shift of the specificity of restriction proteases, and subsequent presentation of these new peptides in the context of the MHC, are conceivable. In experimental models such a metal-induced presentation of new self-antigens recognized as nonself by the immune system has been identified as a cause of autoimmunity $[179,180]$. In sarcoidosis, however, the initiating agent is not known, but it may be found in the membrane of alveolar macrophages, as demonstrated by a granulomatous skin reaction elicited by membrane fragments of sarcoid alveolar macrophages [148].

Many structurally different agents are known to stimulate the formation of immune granulomas and they share some characteristics. Firstly, in the case of infectious agents their habitat is the macrophage or, owing to their particulate nature, they have the propensity to be phagocytosed by macrophages. Secondly, they have the capability to persist within tissues or macrophages, either because the micro-organisms involved are resistant to intracellular killing or because the materials resist enzymatic degradation. Thirdly, without a specific T-cell response immune granuloma cannot be generated and therefore, the inducing agents have to be immunogenic. The unknown aetiological sarcoidosis-inducing agent should fulfil these three criteria.

Granulomas are structured masses composed of activated macrophages and their derivatives, i.e. epitheloid and giant cells. In contrast to the foreign body-type granuloma (e.g. induced by nonimmunogenic silica), the sarcoid granuloma contains more lymphocytes and at times eosinophils, mast cells and fibroblasts. Sequential analysis of the cellular components of these lesions has demonstrated their dynamic nature. An influx, local multiplication and cell death of immune cells can be observed, most probably governed by inflammatory signals. In immune granulomas, as in sarcoidosis, these signals are likely to be cytokines and cell-cell interactions of lymphocytes, macrophages and their derivatives, and fibroblasts [181]. Blocking CD80 and CD86, molecules mediating the accessory signals of macrophages in T-cell activation [131], by monoclonal antibodies suppressed helminth-induced granuloma formation and cytokine release of T-cells, highlighting the interdependence of these processes in granuloma formation [182].

After phagocytosis of the inducing agent the macrophage releases a number of cytokines which mediate migration of activated lymphocytes and monocytes out of the bloodstream into sites of inflammation. Osteopontin, also known as early T-lymphocyte activation protein 1 (Eta-1), a cytokine released by many cells including lymphocytes and monocytes, is shown to promote macrophage migration and adhesion and is secreted by activated T-cells in association with resistance of mice to infection with obligate intracellular bacteria [183]. Eta-1 was released in high quantities by macrophages immediately after the phagocytosis of M. tuberculosis, but only in minute amounts when phagocytosing inert particles. Normal lung and granulation tissue did not stain positive for Eta-1 but it was identified by immunohistochemistry in macrophages, lymphocytes and the extracellular matrix of pathological tissue sections of patients with tuberculosis or silicosis [184]. The formation of granuloma requires the presence of TNF- $\alpha$, IL- 1 , IFN- $\gamma$ and other cytokines. Animal studies of immune and foreign-body granulomas suggest that IL-1 is important in the early recruitment stages of granuloma formation, while TNF- $\alpha$ may take part in later maintenance or effector functions [185]. This view is supported by the observation that depletion of TNF- $\alpha$ led to a rapid regression of fully developed immune granulo-mas and suppressed the accumulation of mRNA in macrophages surrounding the granuloma. The latter indicates that TNF- $\alpha$ enhances its own synthesis and release, thus favouring further macrophage accumulation and differentiation leading to bacterial elimination [186]. The requirement of IFN- $\gamma$ for granuloma formation is demonstrated by the absence of granulomas in IFN- $\gamma$ gene knockout 
mice, which do not respond with a granulomatous reaction after exposure to thermophilic bacteria [187].

The role of T-cells in the development and maintenance of granuloma can be studied in infectious diseases and their animal models. Experimental infection of susceptible mice with Leishmani major results in a disseminated, lethal disease and the infected animals respond with CD4+ Th2 cells secreting IL4, IL-5, IL-6 and IL10 , promoting a humoral and suppressing a cellular immune response. In marked contrast, CD4+ IL- 2, IFN- $\gamma$ and TNF- $\beta$-releasing Th1 cells are observed in resistant strains which respond with a strong cellular immune reaction. Evidence from human leishmaniosis suggests that the Th1 or Th2 polarized response determines whether subclinical or progressive disease develops [188]. Using mycobacterial and schistosomal antigens Type 1 (IFN- $\gamma$ and TNF- $\beta$ dominant) and Type 2 (IL-4 and IL-5 dominant) granulomatous responses can be elicited in normal mice. Knockout of the IFN- $\gamma$ gene converts the Type 1 response to a response with decreased TNF- $\beta$ and increased secretion of IL-4, IL-5 and other Type 2 cytokines and eosinophilic infiltration. IL-4 gene knockout exacerbates Type 1 response with compartmentalization of the expected exaggerated IFN- $\gamma$ release to the lymph nodes and a decrease in IFN- $\gamma$ transcripts in the lung. Most interestingly, IL-4 gene knockout did not convert Type 2 to Type 1 granulomas [189]. Along this line a Type 1 cytokine pattern has to be expected in tuberculous and sarcoid granulomas. BERGERON et al. [190] analysed the presence of mRNA of 16 cytokines in granulomatous lymph node tissue of patients with tuberculosis and sarcoidosis and found a Type 1 response in sarcoidosis and Type 0 response (less polarized to Type 1) in tuberculosis. In addition, they demonstrated that distinct histological features were associated with characteristic cytokine patterns, e.g. neutrophilic infiltration heralded the presence of IL-8 transcripts [190]. Taken together, these studies suggest that a more sophisticated modulation of cytokine expression with other drugs than corticosteroids might be a way of improving the outcome of patients with sarcoidosis and other granulomatous disorders.

\section{Fibrosis}

Granulomas may serve as a focus for fibrosis, with the pattern of fibrosis clearly differing among the various granulomatous disorders. In sarcoidosis a more focal perigranulomatous type is observed. The immune cells composing the granuloma secrete cytokines that attract, stimulate and deactivate fibroblasts, which seems to be dependent on immunological cytokines $[182,191,192]$ such as interferon. The latter could be demonstrated by comparing the IFN- $\gamma$ release of BAL cells from sarcoid lung areas with focal fibrosis with that from areas shown to be free of fibrosis in the computed tomographic (CT) scan [193].

Monitoring the turn-over of cellular matrix in the process of fibrosis should be a way of estimating the status of fibroblasts. Several parameters have been thoroughly evaluated to serve as markers for pulmonary fibrosis, e.g. type III procollagen peptide, collagenase, hyaluronan, and fibrinogen and its degradation products [194-199]. The problem encountered with this concept is that none of the named markers can differentiate between pathological fibrosis and normal tissue turnover in inflammation, as demonstrated by the fact that some markers correlate with parameters of alveolitis [198], although conflicting results have been obtained in longitudinal studies $[196,197]$. Thus, at present clinically applicable parameters to monitor or even predict fibrosis do not exist [200, 201].

\section{Cytokine network}

The interactions of the activated cells described above require mechanisms of signal transduction, the cytokine network of which has been analysed in detail as the required methods have been available since the early 1980s. In this complex network, the effect of an individual cytokine varies with the state of activation of the target cell, the presence of other cytokines in the local microenvironment and the ability of the target cells to produce arachidonic acid metabolites.

By the presence of IL-2 and IFN- $\gamma[88,141,165]$ and the absence of IL4 and IL-5 [126, 190, 204] a functional predominance of Th1 cells can be demonstrated in the lower respiratory tract of patients with sarcoidosis, although the capacity for producing $\mathrm{Th} 2$ cytokines seems to be maintained [168]. One key cytokine for the induction of Th1 cells is IL-12, a product of activated macrophages and a strong inducer of Th1 responses. A higher expression of the bioactive cytokine heterodimer (p70) and the mRNA of the regulated p40 subunit were found by MoLLer et al. [202] in sarcoid BAL cells compared with controls. This increased level of IL-12 upregulates the development of Th1 cells and amplifies the release of Th1 cytokines, especially IFN- $\gamma$.

In the course of sarcoid alveolitis an abundance of cytokines, soluble cytokine receptors and soluble adhesion molecules capable of attracting and activating immune cells and of inducing and maintaining granuloma are released by alveolar macrophages, T-cells and epithelia. Alveolar macrophages release IL-1 and TNF- $\alpha$ [117, 118], pivotal cytokines for the maintenance of granuloma $[185,186]$. Alveolar T-cells activated by alveolar macrophage-derived IL-12 release IL-2, IL-16, INF- $\gamma$ and other cytokines which attract mononuclear cells to the alveoli, activate these cells and induce their proliferation and differentiation [88, 164-167, 203, 204]. In this regard the experimental administration of IL-2 in tumour patients by inhalation is of interest as it revealed that this cytokine activates alveolar macrophages [133] but does not induce further cytokine release [205]. Thus, alveolar T-cells and macrophages activate each other and there is evidence that the cytokine pattern of the alveolitis determines the course of the disease. Elevated levels of IL-2 [206], IL-8 [207-209], TNF- $\alpha$ [40] and MIP-1 $\alpha$ [209] were found in patients with progressing disease, which demonstrates that these immunopathological processes determine the clinical course of sarcoidosis. Moreover, by measuring alveolar macrophage TNF- $\alpha$ release it is possible to identify subgroups of sarcoidosis patients who will suffer from progression in the near future [40]. The observation of a coincidence of manifestation of sarcoidosis with IFN- $\alpha$ therapy of cutaneous T-cell lymphoma or hepatitis C further supports the notion of the pivotal role of the cytokine network in sarcoidosis [210]. 
These phenomena of immune cell activation and cytokine release are compartmentalized and can only be observed in the lung and, although sarcoidosis is considered to be a systemic disorder, no activation of peripheral blood cells could be demonstrated [88, 118, 147, 211]. Using more sensitive methods to detect cytokines in serum or cell culture supernatants an elevated serum level of IFN- $\gamma$ and an increased release of IL-1 $\beta$, IL- 6 and TNF- $\alpha$ by peripheral blood mononuclear cells was recently observed [212-214]. Moreover, an activation of these cells could be demonstrated by identifying IFN- $\gamma$ mRNA transcripts [214]. Owing to the rapid turnover of mononuclear cells in the peripheral blood an activation process in this body compartment seems rather unlikely [215, 216].

The human CXC and CC chemokine families of chemotactic cytokines are closely related mediator families which diverged from a common ancestral gene. Chemokines can be produced by an array of immune and nonimmune cells present in the lung. In sarcoidosis, CC (IL-8) and CXC (MIP-1 $\alpha$, MCP-1, RANTES) have been found in BAL cell culture supernatants and BAL fluid. They mediate a major part of monocyte, lymphocyte and neutrophil chemotactic activity and are capable of activating these cells [110, 111, 116, 209, 217, 218]. In line with this notion is the observation of elevated chemokine release in patients with active or progressing disease [207-209]. In idiopathic pulmonary fibrosis and animal models of this disorder a critical role of CC and CXC chemokines in the initiation and maintenance of pulmonary lesions and their angiogenesis could be established [111, 191, 219]. Studies into pulmonary fibrosis taking place in the course of sarcoidosis are still lacking.

Alveolar cells shed cytokine receptors and adhesion molecules, and in many pulmonary disorders elevated BAL fluid levels of soluble TNF-RI (sTNF-R), sTNF-RII, sIL-2R and intercellular adhesion molecule-1 (sICAM-1) can be found [126]. These molecules are released by alveolar cells $[220,222]$ and elevated serum levels related to the clinical course are observed in active sarcoidosis and other chronic inflammatory disorders [221, 223-226]. BAL cell release and BAL fluid content of these cytokines do not correlate with their respective serum levels [221, 224, 227], which might be explained by the absence of a basal membrane leakage or only a limited defect of the basal membrane in sarcoidosis [228, 229] and a release of these molecules in other compartments of the body with easier access to serum [221, 224, 230]. Only limited data are available on the function of these soluble molecules. However, immunosuppressive functions via competition for cytokines or pro-inflammatory functions via prolongation of the cytokine half-life are conceivable. Recent studies indicate a role for sIL-2R in the regulation of Th1/Th2 responses [231] and an antifibrotic capability of sTNF-R [232]. An anti-inflammatory role for the IL-1 receptor antagonist (IL-1RA), an immune-regulatory molecule found in BAL fluid and granulomatous lesions of sarcoidosis patients [190, 233, 234], was established in animal models [235]. In sarcoidosis, however, the role of these soluble molecules has not yet been established.

IL-6 is a pleiotropic cytokine with critical participation in immunity against intracellular infections. Together with other pro-inflammatory cytokines such as IL-1 and TNF$\alpha$, it is known to be required for the induction of acute phase reactions composed of fever, leukocyte margination, cortisol release and hepatic production of acute phase proteins. While there is little doubt about the pro-inflammatory nature of TNF- $\alpha$ and IL-1, it has remained unclear whether IL-6 is merely an acute phase reaction-inducing mediator or has further immunoregulatory activities. In sarcoidosis IL-6 is coexpressed in activated alveolar mononuclear cells with TNF- $\alpha$, IL- 1 , IL- 2 and IFN- $\gamma[120$, $121,126,167,207,208,212]$, whereas equivocal results have been obtained regarding its expression in sarcoid lymph nodes $[143,190]$. Using IL-6 knockout mice $\mathrm{X}_{\mathrm{ING}}$ et al. [236] demonstrated that IL-6 is critically required to control the extent of local and systemic inflammation by downregulating the expression of pro-inflammatory cytokine genes and upregulating anti-inflammatory molecules. In chronic inflammation, however, IL-6 promotes T-cell activation and proliferation, B-cell proliferation and antibody production. From this it has to be concluded that the role of IL- 6 in sarcoidosis depends on the stage of the disease.

At present, the most extensively investigated deactivating cytokine is IL-10, which inhibits cytokine production as well as proliferation of human monocytes and T-cells [237]. Although several investigators have searched for this molecule, its presence in the alveolitis of sarcoidosis could not be established $[202,238]$, but equivocal results regarding its gene transcription by BAL cells have been obtained [167, 202] and elevated serum levels have been recorded in sarcoidosis patients [211].

Transforming growth factor- $\beta$ (TGF- $\beta$ ) belongs to the superfamily of ubiquitous regulatory proteins which are necessary for cell growth, cell differentiation and regulation of extracellular matrix production. Growing evidence also supports the role of TGF- $\beta$ as an immunomodulator, exhibiting pro-inflammatory and anti-inflammatory activities [239] and inhibiting the development of Th1 cells $[164,240]$. TGF- $\beta$ was found in supernatants of patients with active disease and a spontaneous remission within 6 months after the investigation, whereas patients requiring therapy or suffering from chronic disease disclosed TGF$\beta$ levels that were no different from controls. Furthermore, a strong and significant negative correlation was found between IL- 2 and TGF- $\beta$ production by BAL cells [238]. This suggests an inhibitory role of TGF- $\beta$ on the IL- 2 production of T-cells. In keeping with the literature, it can be concluded from these data that the release of TGF- $\beta$ by BAL cells is indicative of a mechanism which results in the cessation of inflammatory processes. Whether TGF- $\beta$ is the key cytokine in downregulating the alveolitis or whether it acts together with other, still unknown mediators requires further investigation.

In this regard it is of interest that the activation of T-cells via CD28 is resistant to the downregulation by TGF- $\beta$ [242]. In some patients an increased expression of CD80, the ligand of CD28, on alveolar macrophages has been demonstrated, indicating an activation of alveolar Tcells via this pathway [131]. Thus, the course of the disease might be determined by the mode of T-cell activation.

In conclusion, the action of the cytokine network in sarcoidosis can be summarized as follows: an unknown agent activates resident T-cells and macrophages, which subsequently release cytokines (IL-2, IL-12, IL-16, chemokines and IFN- $\gamma$ ), which prime and activate neighbouring cells and are chemotactic for mononuclear cells. The activated cells constitute an alveolitis and the cytokines released 


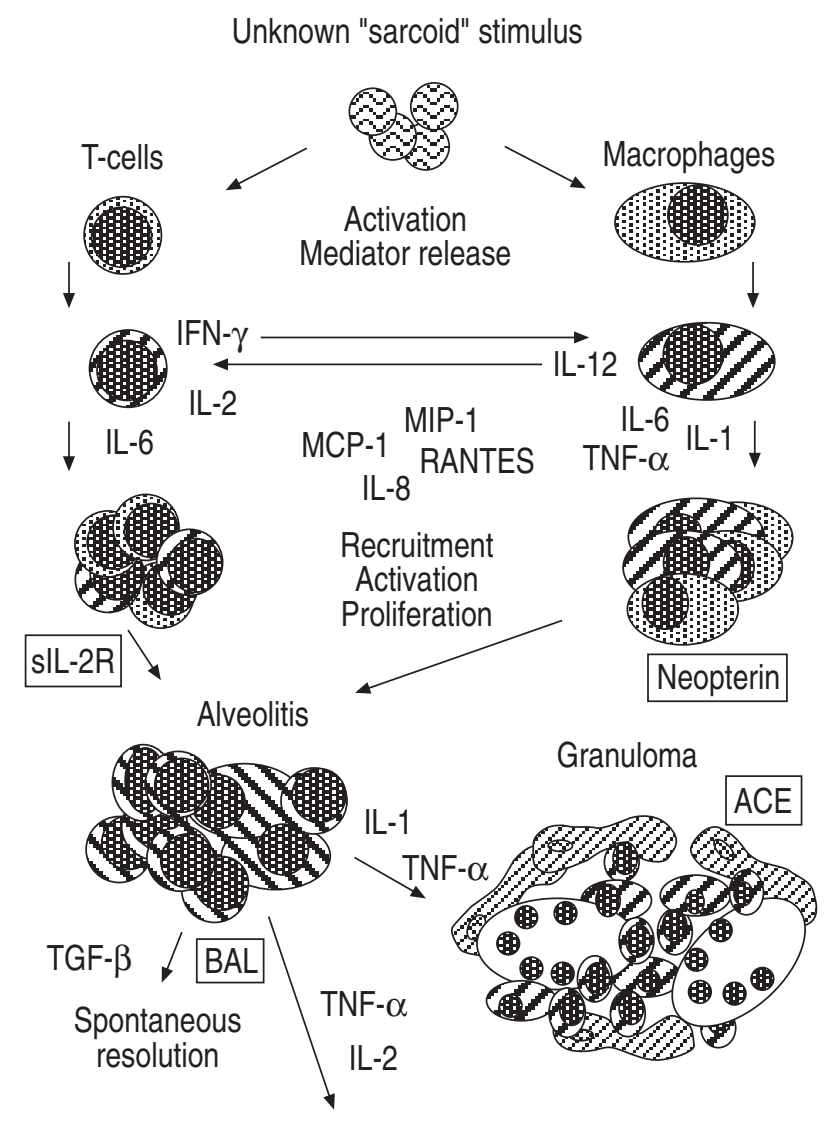

\section{Progressive disease}

Fig. 2. - Concept of the immunopathogenesis of sarcoidosis. An unknown "sarcoid" stimulus activates quiescent T-cells and macrophages and elicits cytokine release. The cytokines perpetuate recruitment, activation and proliferation of mononuclear cells, generate an alveolitis, promote granuloma formation and influence the clinical course of the disease. Several steps of this concept can be probed by clinical parameters, indicated in the boxes. sIL-2R: soluble interleukin (IL)-2 receptor; ACE: angiotensin-converting enzyme; BAL: bronchoalveolar lavage; IFN- $\gamma$ : interferon-gamma; TNF- $\alpha$ : tumour necrosis factor-alpha; MIP1: macrophage inflammatory protein-1; MCP-1: monocyte chemotactic peptide-1; RANTES: regulated on activation, normal T-cell expressed and secreted chemokine; TGF- $\beta$ : transforming growth factor-beta.

(IL- 1 and TNF- $\alpha$ ) induce and maintain granuloma, which might contain the unknown "sarcoid agent". These processes determine the clinical course of the disease in as much as the predominance of pro-inflammatory cytokines heralds progression and TGF- $\beta$ a spontaneous resolution of the disease (fig. 2). From this concept several serological parameters gauging disease activity and of prognostic value have been delineated (see below).

\section{Disease modifying genes}

The HLA complex plays a pivotal role in the immune response by presenting antigens for T-cell recognition and defining the self-epitopes tolerated by the immune system. Distinct HLA class II alleles confer both predisposition and resistance to immune-related disorders. In primary biliary cirrhosis distinct haplotypes confer resistance and others are significantly increased in patients with the disease [242, 243]. For sarcoidosis loose positive and neg- ative HLA linkages have been observed in numerous studies, but a clear-cut linkage disequilibrium with a distinct HLA class II allele has not been found [17, 18, 244]. In Scandinavian patients the clinically defined subgroup of severe chronic disease exhibited an under-representation of HLA-DR3 and an over-representation of HLA-DRw6 [17], which indicates that the course of the disease is modified by HLA class II alleles.

In a longitudinal study by BerLin et al. [245] 122 Scandinavian patients were genotyped for HLA class II alleles and clinically monitored for over $10 \mathrm{yrs}$. They found a significantly increased frequency of HLA-DR17 (old nomenclature DR3) in patients with nonchronic disease lasting $<2$ yrs (65 versus $17 \%$ in controls). Patients developing chronic disease, however, exhibited an over-representation of DR14 (formerly DR6) and DR15 (formerly DR2). For patients with Löfgren's syndrome 19 out of 19 of DR17+ and two out of four of DR17- patients recovered within 2 yrs. Furthermore, a strong association of HLA-DQB ${ }^{*}$ 0201/0202 with nonchronic and of HLA-DQB $1 * 0503$ and HLA-DQ*0602 alleles with chronic disease was observed. Thus, genotyping of these Scandinavian patients allowed a subgrouping of patients into categories with significantly different clinical courses. Unfortunately, these results cannot be extrapolated to other ethnic populations since differences in protection and susceptibility conferring alleles have been observed for other diseases [243] and for sarcoidosis those differences are reported between Caucasian ethnic groups [31] and between Scandinavians and Japanese [246]. Nevertheless, this approach seems applicable for a clinical categorization of sarcoidosis patients.

These studies demonstrate that a predisposition to sarcoidosis is hereditary and implicate genes of the HLA locus as necessary but not sufficient determinants of sarcoidosis. However, it has to be kept in mind that only a small fraction of those who carry the implicated HLA susceptibility alleles develop disease and it is difficult to demonstrate that the HLA associations observed are due to formal genetic linkage between the disease and the HLA locus. The possible role of environmental factors in sarcoidosis and other diseases with a genetic background cannot be denied and the participation of additional genes, not necessarily linked to HLA, has to be tested.

In this context the disease-modifying capabilities of a promoter polymorphism of TNF- $\alpha$ are of interest. At position -308 in the promoter region of the TNF- $\alpha$ gene a biallelic polymorphism has been identified which is associated with variation of TNF- $\alpha$ production in health and disease. Recently, this polymorphism has been correlated with susceptibility to severe disease such as cerebral malaria [247], mucocutaneous leishmaniasis [248], chronic bronchitis [249] and poor prognosis in severe sepsis [250] conferred by the TNFA 2 allele. These studies suggest that susceptibility to these diseases may be directly associated with regulatory polymorphisms increasing TNF- $\alpha$ production.

Since cytokine production and in particular TNF- $\alpha$ release by alveolar macrophages is a crucial feature of the immunopathogenesis of sarcoidosis [118], with even prognostic relevance [40], an analysis of the TNF promoter polymorphism was warranted. The TNFA2 allele was shown to confer a six- to seven-fold higher basal and induced TNF- $\alpha$ mRNA transcription than the more frequent allele (TNFA1) [251]. Although its assumed effect of 
elevated TNF- $\alpha$ levels in vivo has not yet been clearly demonstrated, this seems likely because children who developed cerebral complications of malaria were more prone to carrying the TNFA2 homozygote genotype and had higher TNF- $\alpha$ serum levels [247].

The TNFA1/TNFA2 polymorphism was studied in 101 patients with sarcoidosis and 216 controls and a significant shift to the TNFA2 allele in Löfgren's syndrome was shown $($ TNFA1/TNFA2 $=0.59 / 0.41$ versus $0.81 / 0.19$ in controls, $\mathrm{p}>0.01$ ). Comparing Löfgren's syndrome with nonacute sarcoidosis also revealed a significant shift towards the less common TNFA2 allele in Löfgren's syndrome. The entire sarcoidosis cohort, however, did not differ in their TNFA1/TNFA2 allele frequency from control (0.77/ 0.23 ). Thus, in contrast to the diseases cited above for patients with sarcoidosis the TNFA2 allele seems to confer a good prognosis [252]. However, in an ongoing study of the author's laboratory the expected exaggerated TNF$\alpha$ release of patients with TNFA2 allele could not be demonstrated, casting some doubt on the pathogenic relevance of this association. Compared with phenotype analysis, such as quantifying alveolar macrophage TNF- $\alpha$ release, genotype analysis is an indirect measure and provides only categorical data. However, the phenotype may change with either environmental exposure, disease processes or even with sex as the presence of soluble TNF receptors in serum and BAL in sarcoidosis and other interstitial lung diseases has demonstrated [223, 253, 254] and different TNF- $\alpha$ serum levels were measured in male and female sepsis patients (J. Schröder, unpublished data).

The TNF gene resides in the MHC class III region and the TNFA2 allele was found to be in a linkage disequilibrium with some HLA alleles; among others, in Caucasians with HLA-DR17 [255]. In Scandinavian patients with sarcoidosis HLA-DR17 conferred a good prognosis [245]. Thus, TNFA2 may constitute a passive component of the "Löfgren haplotype", however, on the basis of the available data the opposite cannot be excluded. The increased frequency of the TNFA2 allele in some immune-related disorders may be dependent on its association with HLADR17 [256, 257]. In children with manifestations of cerebral malaria, however, an association with HLA class I or class II alleles was not observed [247]. In this context, the notion of ethnical differences in the frequencies of the TNF promoter polymorphism is noteworthy and in a Japanese study the TNFB1 allele was over-represented in patients with sarcoidosis; however, on the basis of the known association between HLA-B and TNFB alleles in the Japanese population this over-representation has to be regarded as extended disease-associated haplotypes of the HLA locus [258]. Thus, in sarcoidosis as in other disorders the interpretation of associations of TNFA and TNFB polymorphisms is difficult owing to linkage disequilibrium between these alleles and HLA class I and II alleles.

\section{Delineated markers}

\section{Bronchoalveolar lavage markers}

Since BAL probes the compartment of the body most frequently harbouring critical immune mechanisms of sarcoidosis it was assumed that clinical parameters of BAL would be the best approach by which to estimate the inflammatory activity of sarcoidosis and many cytological parameters have been suggested. Follow-up studies, however, revealed ambiguous data and thus the prognostic value of this approach was questioned. Activation markers such as the expression of HLA-DR or IL-2R indicate an activation of BAL cells, but the extent of these phenomena does not allow the separation of patients into groups with different, clear-cut clinical characteristics [135, 137]. Initially, the low numbers of cells expressing those markers was surprising, however, this expectation was based on in vitro studies in which first-order reactions take place [259]. In vivo saturating levels of antigen, helper and Tcells are not provided and in these rate-limiting situations second- or even third-order reactions that generate completely different characteristics of activated cells might dominate. Thus, the transfer of in vitro phenomena of immunoregulation to immunopathological in vivo situations might lead to false expectations and the observed relatively low numbers of BAL cells expressing activation markers might well be a physiological outcome of T-cell antigen interactions with only weak stimulatory capacity. Following those sarcoidosis patients with $>40 \%$ HLA-DR expressing BAL T-cells revealed 14 out of 15 cases with progressive disease [260], which demonstrates that strong activation processes correlate with an unfortunate clinical course.

A parameter with some prognostic value is the CD4/ CD8 ratio of BAL T-cells which, in the case of a strong elevation, indicates a good prognosis and is associated with chronic disease when a lower ratio is observed [261263]. Other researchers, however, could not establish a clear prognostic value of this parameter [40].

Ambiguous results regarding the prognostic value of the percentage of lymphocytes have been obtained [40, 264-268], but the combination of the percentage of BAL lymphocytes with the spontaneous in vitro IL-2 release of these cells reveals that patients with elevated numbers of IL-2 releasing BAL lymphocytes have the propensity to suffer from progressive disease [206]. Functional parameters obtained by tissue culture of BAL cells or by measuring cytokines in BAL fluid are difficult to obtain in clinical routine but they demonstrate that immunological processes are critical for the clinical outcome.

The observation of heterogeneous TNF- $\alpha$ release by alveolar macrophages in groups of sarcoidosis patients with active/inactive disease [118], good/poor prognosis [238] or with/with out therapy [269] led the author to conduct a follow-up study correlating spontaneous alveolar macrophage TNF- $\alpha$ release with the course of the disease. The heterogeneous TNF- $\alpha$ release was reproduced, showing both elevated and normal levels in groups of patients with fortunate and progressing course or with and without therapy. In those patients who had no indication of therapy at the time of BAL an elevated alveolar macrophage TNF- $\alpha$ release marked a significantly higher risk of deterioration requiring therapy [40]. In those patients with indications for therapy at the time of BAL this parameter showed a trend towards a higher rate of therapy failure in the subgroup with elevated TNF- $\alpha$ release [40]. Thus, the analysis of alveolar macrophage cytokine release can help to identify subgroups of sarcoidosis patients with different risk patterns for deterioration or failure of therapy. Note, that this information cannot be extracted from pulmonary function tests [40, 269]. 


\section{Serum markers}

In a routine setting sequential BAL are not practical and serum markers are required. Several molecules shed by activated immune cells or epithelia build elevated serum levels which may be used to probe the corresponding immune processes. At present, practical parameters are available for the granuloma burden, T-cell activation and macrophage/monocyte activation.

ACE and lysozyme are molecules secreted by epitheloid cells and their serum levels indicate the total body granuloma burden [39]. The sensitivity, specificity and prognostic value of these parameters are low [40, 270, 271] (fig. 3), but the detection of an insertion/deletion polymorphism of the ACE gene, which influences the ACE

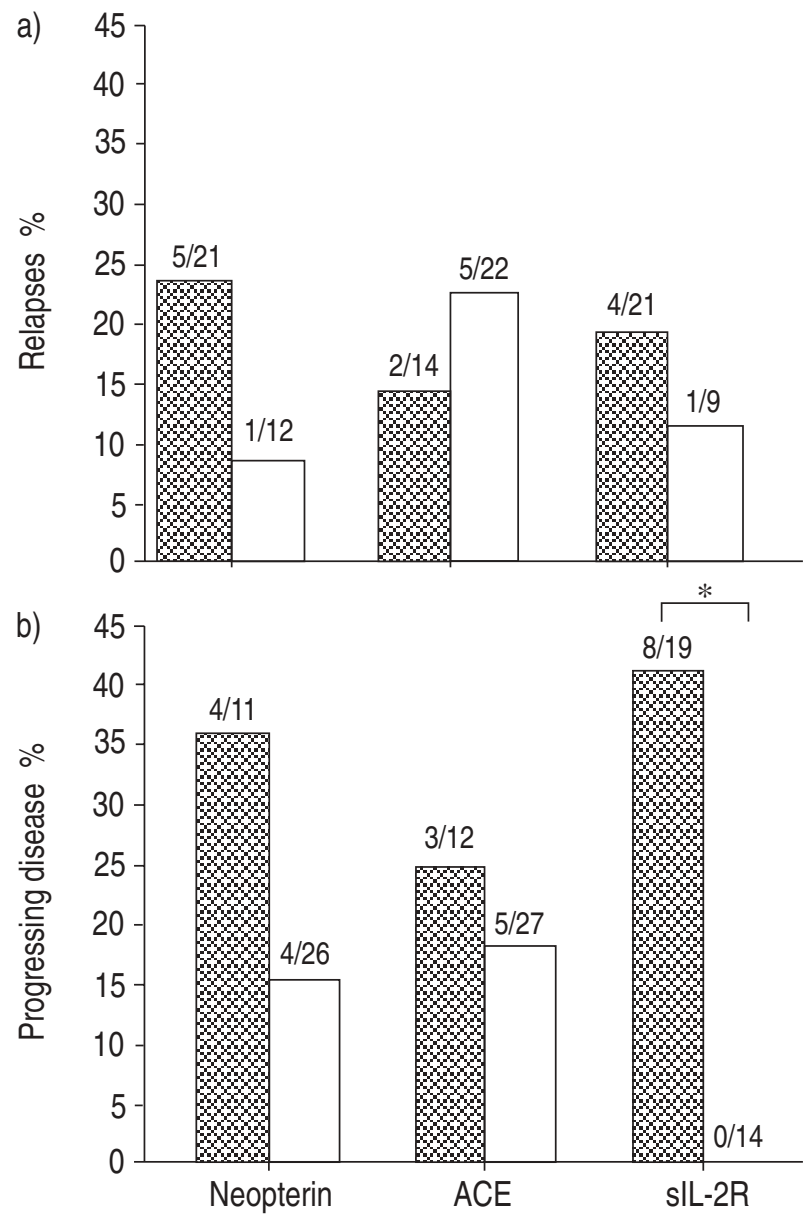

Fig. 3. - Prognostic value of serological parameters of disease activity of sarcoidosis. a) Sarcoidosis patients with indications for therapy (group A) and b) without indications for therapy (group B) were divided into subgroups either with high ( $\$$ ) or normal ( $\square$ ) levels of the investigated parameters. Relapses during tapering of corticosteroids or after cessation of therapy in group $\mathrm{A}$, or progressive disease requiring therapy in group B, served as endpoints as determined by a follow-up, and are given as percentages on the ordinates. ACE: angiotensin-converting enzyme. The numbers of relapses or cases of progressive disease within the total number of patients in each subgroup are given at the tops of the bars. Sarcoidosis patients with no indication for therapy and high levels of soluble interleukin-2 respecters (sIL-2R) had a significantly greater risk of disease progression $(*: p=0.017)$ than those with a normal sIL-2R level. In both groups, patients with a high serum level of neopterin had a greater risk of relapse or disease progression, although this difference was not statistically significant. (Reproduced from [40] with permission.) level of healthy individuals, opens up the possibility of using genotype-corrected normal values, which may be of greater prognostic value [34-37].

Neopterin, a small, 250 molecular weight metabolite of the guanosine triphosphate pathway, is released by activated macrophages and monocytes [272]. It gauges the inflammatory activity of these cells rather than their activation in the course of building granulomas. As expected, elevated serum levels were found in sarcoidosis and are used to monitor the activity of cells of the macrophage/ monocyte lineage [273-275]. No correlation between BAL cell-released TNF- $\alpha$ or IL- 6 with serum neopterin could be observed [120], giving rise to the hypothesis that the elevated neopterin levels are sequelae of cell activations in body compartments other than the alveolar space, such as lymph nodes, providing secreted molecules with easy access to the serum. Nevertheless, serum or urine neopterin concentrations proved to be useful clinical parameters to probe the activity of the cells of the monocyte/ macrophage lineage in the course of sarcoidosis [273276].

Numerous serum parameters are suggested to gauge the activity of T-cells. Adenosine deaminase and soluble CD27 are sporadically used to estimate the inflammatory activity of sarcoidosis [277-279], however, of the available parameters soluble IL-2R (sIL-2R) is most frequently used for this purpose. sIL-2R can be found in BAL fluid and serum of sarcoidosis patients and it is released by activated alveolar immune cells [221, 280-282]. In addition to lymphocytes, macrophages are capable of expressing IL-2R upon activation and it has been demonstrated that up to $50 \%$ of activated sarcoid alveolar macrophages exhibit increased numbers of IL-2R [283]. The relative contribution of lymphocytes and macrophages to the alveolar lining fluid sIL-2R concentration is not known [221, 283]. The absence of a correlation between alveolar macrophage TNF- $\alpha$ release as marker of cell activation and BAL fluid sIL-2R concentration argues in favour of sIL2R being a T-lymphocyte marker [118].

A study of our laboratory evaluated the predictive value of serum levels of ACE, neopterin and sIL-2R in patients with newly diagnosed sarcoidosis and only sIL-2R was of significant prognostic value. In the author's study group, $41.2 \%$ of the patients with no indication for therapy at time point of BAL and increased serum levels of sIL-2R experienced disease progression requiring corticosteroid therapy, whereas none of those with normal level did (Group B, fig. 3). In those patients with indication for therapy at time of investigation both outcome subgroups (with and without treatment failure) had, on average, an increased initial sIL-2R. Although it was not significant, a similar trend toward higher risk of relapse could be observed in those patients with indication for therapy (Group A, fig. 3). The predictive values of ACE and neopterin are still under consideration, but in the author's study groups neither yielded significant prognostic information, although a trend towards unfortunate clinical outcome was observed in those with elevated values of neopterin (fig. 3) [40].

It has to be kept in mind that none of the above-mentioned parameters can be used to establish a diagnosis or to find an indication for therapy, as elevated levels are found in a number of diseases and inflammatory activity may not be the therapeutic target. Once the diagnosis of 
sarcoidosis has been made, the inflammatory activity of some immunopathogenetic processes can be monitored by the use of these serum parameters.

\section{Treatment}

\section{Corticosteroids}

Because of the variable course of sarcoidosis and potential for spontaneous remissions, indications for therapy are still controversial. Fortunately, many patients will not require treatment because the symptoms are not disabling and frequently remit spontaneously. M. Sones and associates and Siltzbach, the first to report the remedial effects of short-term corticosteroid therapy of sarcoidosis, observed histological improvement paralleling other signs of improvement and concluded that this therapy prevents progression of the disorder, although, at the same time, they noted a high rate of relapses after cessation of therapy (reviewed in [284]). Many open and placebo-controlled studies questioned the conclusion of the salutary effects of corticosteroids on the course of sarcoidosis. A major obstacle of those studies is the inability to predict reliably which patients will spontaneously recover and which will deteriorate, and much controversy exists about the criteria for measurement of success. However, extensive clinical experience favours treating patients with severe pulmonary or extrapulmonary disease.

Corticosteroids are clearly necessary for life- or sightthreatening organ involvement, e.g. ocular, cardial, central nervous system, hypercalcaemia or disfiguring cutaneous involvement. Studies used to support the conclusion that corticosteroids are of no benefit gave data which clearly demonstrate the opposite. After a three-month trial IsRAEL $e t$ al. [285] documented an improvement in 53\% of treated patients with radiological types II and III versus $16 \%$ in the control group. A follow-up study of 5 yrs, however, failed to document a benefit. Similarly, ZAKI et al. [286] treated 183 patients with all radiological types, presumably including asymptomatic patients, and observed an $11 \%$ deterioration in the placebo group but only $5 \%$ in the treatment group. In a recent study from the UK, asymptomatic patients with persistent radiographic infiltrates were randomized to receive either prednisolone for $1 \mathrm{yr}$ or no therapy. Both groups were followed for 5 yrs and a $9 \%$ higher vital capacity, lower rate of symptoms and improved chest radiographic findings were recorded for the treatment group [287]. This can be taken as good evidence that corticosteroids attenuate or even avert loss of pulmonary function in patients with radiographic types II and III, even in asymptomatic patients.

From a theoretical point of view a beneficial effect of corticosteroids can be assumed since the administration of this drug effectively suppresses the process of alveolar Tcell IL-2 release and the proliferation of these cells [203]. These are two pivotal characteristics of the alveolitis of sarcoidosis and the IL-2 release is linked with disease progression [206]. In a prospective study by HunNinghaKe et al. [107] only sarcoidosis patients with evidence of recent deterioration of lung function or severe extrapulmonary disease were treated with corticosteroids for 12 months. Finding the indication for therapy on the basis of these clinical criteria, it was demonstrated that treatment prevented deterioration or induced improvement in lung function. Thus, the ongoing inflammatory processes causing deterioration of lung function can be obstructed and further deterioration can be prevented. (For detailed specifications of the standard of therapy the reader is referred to the literature $[1,288]$.)

\section{Alternative drugs}

For patients with contra-indications for corticosteroids or corticosteroid-recalcitrant sarcoidosis a variety of other anti-inflammatory or immunosuppressive approaches have been evaluated in uncontrolled studies or case reports. For methotrexate [289], azathioprine (Müller-Quernheim et al., unpublished data) and cyclosporin A [290] a corticosteroid-sparing effect can be accepted and its use is suggested in patients who need prolonged therapy with high doses of corticosteroids [291]. For detailed recommendation regarding doses and mode of therapy the reader is referred to clinical reviews [288, 291, 292].

Although cyclosporin A is effective in vitro in suppressing the exaggerated activation of sarcoid alveolar T-cells, it does not do so in vivo, as demonstrated in a study using this drug as a monotherapeutic agent [293]. In contrast, for methotrexate some usefulness as a monotherapeutic drug capable of replacing low-dose corticosteroids was demonstrated and its capacity to suppress immunopathological processes of sarcoidosis such as release of TNF- $\alpha$ and radical oxygen intermediates was recorded [294]. A corticosteroid-sparing effect of methotrexate was observed in a larger series and in some patients prednisolone was discontinued, while methotrexate maintained remission [289]. In a similar way it could be demonstrated that the combination of azathioprine and prednisolone allowed the reduction of corticosteroids, while the suppression of alveolar leukocytes IL-2 and TNF- $\alpha$ release endured and the clinical improvement was sustained (Müller-Quernheim et al., unpublished data). The described concept of the immunopathogenesis of sarcoidosis provides a tool which allows the gauging of the effect of a treatment strategy on critical disease processes that might support or discourage the strategy under scrutiny.

Pentoxifylline inhibits both the primary proliferative response of T-cells in the mixed lymphocyte culture [295] and the endotoxin-induced TNF- $\alpha$ release on the transcriptional level both in vitro and in vivo [296, 297]. The release of IL-12, a mediator promoting the Th1-type of Tcells characteristic for the alveolitis of sarcoidosis, is suppressed by pentoxifylline in a way independent of other known IL-12 inhibitors [298]. Moreover, in combination with dexamethasone, an over-additive effect in the inhibition of in vitro stimulated IL-12 [298], IL-2, IFN- $\gamma$ and TNF- $\alpha$ [299] release was observed, which suggested that pentoxifylline might be a drug capable of downregulating the exaggerated cytokine release of sarcoidosis. Indeed, in an open clinical study, 11 out of 18 patients with sarcoidosis treated with pentoxifylline monotherapy improved and in patients with corticosteroid-resistant disease, the addition of pentoxifylline allowed the reduction of prednisolone doses in two cases and even the discontinuation of prednisolone in another case, while the remission achieved with the combination was sustained [300]. 
In 1965, SHESKIN [301] reported 6 cases of acute, severe leprosy reactions in which symptoms resolved quickly and dramatically after the use of thalidomide as a sedative. Recent investigations revealed that thalidomide is a drug capable of selective downregulation of several pro-inflammatory cytokines critically involved in the pathogenesis of sarcoidosis and other granulomatous disorders. It inhibits the in vitro release of IL-12 [302] and TNF- $\alpha$ [303] and acts on alveolar macrophages [304]. Thalidomideinduced inhibition of IL-12 production was additive to that induced by suboptimal inhibiting doses of dexamethasone, giving rise to the hypothesis that the administration of thalidomide is another corticosteroid-sparing option in the treatment of sarcoidosis. This is supported by a recent case report of successful treatment of cutaneous sarcoidosis with thalidomide [305].

\section{Conclusions}

It is becoming increasingly clear that the action of any individual cytokine is neither completely beneficial nor totally detrimental to the host. Rather, a fine balance of cytokine production and regulation must be maintained to ensure that the host can effectively respond to invading micro-organisms or other disturbances of homeostasis without compromising host well-being in the process. Although the aetiology of sarcoidosis remains elusive, better understanding of the regulation of the network of inflammatory cells and cytokines provides a rationale for designing markers of inflammatory activity of the disease and new therapeutic interventions to prevent the damaging immune-mediated pathology.

\section{References}

1. Newman LS, Rose CS, Maier LA. Medical progress: sarcoidosis. N Engl J Med 1997; 336: 1224-1234.

2. Myrvik Q, Leake E, Farris B. Studies on pulmonary alveolar macrophages from the normal rabbit: a technique to procure them in a high state of purity. J Immunol 1961; 86: $128-136$.

3. Reynolds H. State of the art: bronchoalveolar lavage. Am Rev Respir Dis 1987; 135: 250-263.

4. Hunninghake GW, Crystal RG. Pulmonary sarcoidosis: a disorder mediated by excess helper T-lymphocyte activity at sites of disease activity. $N$ Engl J Med 1981; 305: 429434.

5. Teirstein AS, Lesser M. Worldwide distribution and epidemiology of sarcoidosis. In: Fanburg B, ed. Sarcoidosis and Other Granulomatous Diseases of the Lung. Basel, Dekker, 1983; pp. 101-134.

6. Löfgren S. Primary pulmonary sarcoidosis. Acta Med Scand 1953; 145: 424-465.

7. Veien NK. Cutaneous sarcoidosis: prognosis and treatment. Clin Dermatol 1986; 4: 75-87.

8. Rybicki BA, Major M, Popovich J Jr, Maliarik MJ, Iannuzzi MC. Racial differences in sarcoidosis incidence: a 5 -year study in health maintenance organization. $\mathrm{Am} \mathrm{J}$ Epidemol 1997; 145: 234-241.

9. Viskum K, Vestbo J. Vital prognosis in intrathoracic sarcoidosis with special reference to pulmonary function and radiological stage. Eur Respir J 1993; 6: 349-353.

10. Vestbo J, Viskum K. Respiratory symptoms at presenta- tion and long-term vital prognosis in patients with pulmonary sarcoidosis. Sarcoidosis 1994; 11: 123-125.

11. Maná J, Badrinas F. Prognosis of sarcoidosis. An unresolved issue. Sarcoidosis 1992; 9: 15-20.

12. Israel H, Karlin P, Menduke H, DeLisser O. Factors affecting outcome of sarcoidosis: influence of race, extrathoracic involvement, and initial radiologic lung lesions. Ann NY Acad Sci 1986; 465: 609-618.

13. Olive K, Kataria Y. Cutaneous manifestations of sarcoidosis. Relationships to other organ system involvement, abnormal laboratory measurements, and disease course. Arch Intern Med 1985; 145: 1811-1814.

14. Keller AZ. Hospital, age, racial, occupational, geographical, clinical and survivorship characteristics in the epidemiology of sarcoidosis. Am J Epidemiol 1971; 94: 222-230.

15. Rybicki BA, Harrington D, Major M, et al. Heterogeneity of familial risk in sarcoidosis. Genet Epidemiol 1996; 13: 23-33.

16. Jörgensen G. Die Genetik der Sarkoidose. Acta Med Scand 1964; 425: Suppl. 209-212.

17. Odum N, Milman N, Jakobsen BR, Georgsen J, Svejgaard A. HLA class II (DR, DQ, DP) in patients with sarcoidosis: evidence of an increased frequency of DRw6. Exp Clin Immunogenet 1991; 8: 227-232.

18. Martinetti M, Tinelli C, Kolek V, et al. "The sarcoidosis map": a joint survey of clinical and immunogenetic findings in two European countries. Am J Respir Crit Care Med 1995; 152: 557-564.

19. Vyse TJ, Todd JA. Genetic analysis of autoimmune disease. Cell 1996; 85: 311-318.

20. Hugot JP, Laurent P, Gower-Rousseau C, et al. Mapping of a susceptibility locus for Crohn's disease on chromosome 16. Nature 1997; 379: 821-823.

21. Rybicki BA, Maliarik MJ, Major M, Popovich J Jr, Iannuzzi MC. Genetics of sarcoidosis. Clin Chest Med 1997; 18: 707-717.

22. Wordsworth P. Genes and arthritis. Br Med Bull 1995; 51: 249-266.

23. Satsangi J, Welsh KI, Bunce M, et al. Contribution of genes of the major histocompatibility complex to susceptibility and disease phenotype in inflammatory bowel disease. Lancet 1996; 347: 1212-1217.

24. Risch N. Assessing the role of HLA-linked and unlinked determinants of disease. Am J Hum Genet 1987; 40: 1-14.

25. Hochberg MC. The application of genetic epidemiology to systemic lupus erythematosus. J Rheumatol 1987; 14: 867-869.

26. Gregory WL, Bassendine MF. Genetic factors in primary biliary cirrhosis. J Hepatol 1994; 20: 689-692.

27. Tromp G, Kuivaniemi H, Raphael S, et al. Genetic linkage of familial granulomatous inflammatory arthritis, skin rash, and uveitis to chromosome 16. Am J Hum Genet 1996; 59: 1097-1107.

28. Kirsten D. Sarkoidose in Deutschland. Pneumologie 1995; 49: 378-382.

29. Richeldi L, Sorrentino R, Saltini C. HLA-DPB 1 glutamate 69: a genetic marker of beryllium disease. Science 1993; 262: 242-244.

30. Saltini C, Sorrentino R, Richeldi L, Luisetti M, Bisetti A. Role of the HLA-DP gene in susceptibility to lung granulomas. Sarcoidosis 1993; 10: 171-172.

31. Foley P, Lympany P, Puscinska E, et al. HLA-DPB1 and TAP1 polymorphisms in sarcoidosis. Chest 1997; 111: Suppl, 73S.

32. Lympany PA, Petrek M, Southcott AM, Newman Taylor AJ, Welsh KI, du Bois RM. HLA-DPB polymorphisms: 
Glu 69 association with sarcoidosis. Eur J Immunogenet 1996; 23: 353-359.

33. Schürmann M, Bein G, Kirsten D, Schlaak M, MüllerQuernheim J, Schwinger E. HLA-DQB1 and HLA-DPB1 genotypes in familial sarcoidosis. Respir Med 1998; 92: 649-652.

34. Furuya K, Yamaguchi E, Itoh A, et al. Deletion polymorphism in the angiotensin I converting enzyme (ACE) gene as a genetic risk factor for sarcoidosis. Thorax 1996; 51: 777-780.

35. Arbustini E, Grasso M, Leo G, et al. Polymorphism of angiotensin-converting enyme gene in sarcoidosis. Am J Respir Crit Care Med 1996; 153: 851-854.

36. Sharma P, Smith I, Maguire G, Stewart S, Shneerson J, Brown MJ. Clinical value of ACE genotyping in diagnosis of sarcoidosis. Lancet 1997; 349: 1602-1603.

37. Tomita H, Ina Y, Sugiura Y, et al. Polymorphism in the angiotensin-converting enzyme (ACE) gene and sarcoidosis. Am J Respir Crit Care Med 1997; 156: 255-259.

38. Schürmann M, du Bois RM, Reichel P, et al. Genetic studies in familial sarcoidosis. Am J Respir Crit Care Med 1988; 157: A30.

39. Gilbert S, Steinbrech DS, Landas SK, Hunninghake GW. Amounts of angiotensin-converting enzyme mRNA reflect the burden of granulomas in granulomatous lung disease. Am Rev Respir Dis 1993; 148: 483-486.

40. Ziegenhagen MW, Benner UK, Zissel G, Zabel P, Schlaak M, Müller-Quernheim J. Sarcoidosis: TNF-alpha release from alveolar macrophages and serum level of sIL-2R are prognostic markers. Am J Respir Crit Care Med 1997; 156: $1586-1592$.

41. Redondo P, Espana A, Sola J, Rocha E, Quintanilla E. Sarcoid-like granulomas secondary to herpes simplex virus infection. Dermatology 1992; 185: 137-139.

42. Kuwano K, Nomoto Y, Kunitake R, et al. Detection of adenovirus E1A DNA in pulmonary fibrosis using nested polymerase chain reaction. Eur Respir J 1997; 10: 14451449.

43. Di Alberti L, Piattelli A, Artese L, et al. Human herpesvirus 8 variants in sarcoid tissues. Lancet 1997; 350: 16551661.

44. Kedes DH, Operskalski E, Busch M, Kohn R, Flood J, Ganem D. The seroepidemiology of human herpesvirus 8 (Kaposi's sarcoma-associated herpesvirus): distribution of infection in KS risk groups and evidence for sexual transmission. Nat Med 1996; 2: 918-924.

45. Gao SJ, Kingsley L, Hoover DR, et al. Seroconversion to antibodies against Kaposi's sarcoma-associated herpesvirus-related latent nuclear antigens before the development of Kaposi's sarcoma. N Engl J Med 1996; 335: 233-241.

46. Kikuta H, Itakura O, Ariga T, Kobayashi K. Detection of human herpesvirus 8 DNA sequences in peripheral blood mononuclear cells of children. J Med Virol 1997; 53: 8184.

47. Rettig MB, Ma HJ, Vescio RA, et al. Kaposi's sarcomaassociated herpesvirus infection of bone marrow dendritic cells from multiple myeloma patients. Science 1997; 276: 1851-1854.

48. Monini P, de Lellis L, Fabris M, Rigolin P, Cassai E. Kaposi's sarcoma-associated herpesvirus DNA sequences in prostate tissue and human semen. N Engl J Med 1996; 334: 1168-1172.

49. Davis DA, Humphrey RW, Newcomb FM, et al. Detection of serum antibodies to a Kaposi's sarcoma-associated herpesvirus-specific peptide. J Infect Dis 1997; 175: 1071-1079.

50. Lennette ET, Blackbourn DJ, Levy JA. Antibodies to human herpesvirus type 8 in the general population and in Kaposi's sarcoma patients. Lancet 1996; 348: 858861.

51. Di Alberti L, Ngui SL, Porter SR, et al. Presence of human herpesvirus 8 variants in the oral tissues of human immunodeficiency virus-infected persons. J Infect Dis 1997; 175: 703-707.

52. Popper HH, Klemen H, Hoefler G, Winter E. Presence of mycobacterial DNA in sarcoidosis. Hum Pathol 1997; 28: 796-800.

53. Vanek J, Schwarz J. Demonstration of acid-fast rods in sarcoidosis. Am Rev Respir Dis 1970; 101: 395-400.

54. Almenoff PL, Johnson A, Lesser M, Mattman LH. Growth of acid-fast $\mathrm{L}$ forms from the blood of patients with sarcoidosis. Thorax 1996; 51: 530-533.

55. Mitchell I, Turk J, Mitchell D. Detection of mycobacterial rRNA in sarcoidosis with liquid-phase hybridisation. Lancet 1992; 339: 1015-1017.

56. Saboor S, Johnson N, McFadden J. Detection of mycobacterial DNA in sarcoidosis and tuberculosis with polymerase chain reaction. Lancet 1992; 339: 1012-1015.

57. Bocart D, Lecossier D, de Lassence A, Valeyre D, Battesti J-P, Hance AJ. A search for mycobacterial DNA in granulomatous tissues from patients with sarcoidosis using the polymerase chain reaction. Am Rev Respir Dis 1992; 145: 1142-1148.

58. Gerdes J, Richter E, Rüsch-Gerdes S, et al. Mycobacterial nucleic acids in sarcoid lesions. Lancet 1992; 339: 1536-1537.

59. Ghossein RA, Ross DG, Salomon RN, Rabson AR. A search for mycobacterial DNA in sarcoidosis using the polymerase chain reaction. Am J Clin Pathol 1994; 101: 733-737.

60. Vokurka M, Lecossier D, du Bois RM, et al. Absence of DNA from mycobacteria of the $M$. tuberculosis complex in sarcoidosis. Am J Respir Crit Care Med 1997; 156: 1000-1003.

61. Badrinas F, Morera J, Fité E, Plasencia A. Seasonal clustering of sarcoidosis. Lancet 1989; 334: 455-456.

62. Parkes S, Baker SdC, Bourdillon R, Murray C, Rakshit M. Epidemiology of sarcoidosis in the Isle of Man -1: a case controlled study. Thorax 1987; 42: 420-426.

63. Kern D, Neill M, Wrenn D, Varone J. Investigation of a unique time-space cluster of sarcoidosis in firefighters. Am Rev Respir Dis 1993; 148: 974-980.

64. Edmondstone W. Sarcoidosis in nurses: is there an association? Thorax 1988; 43: 342-343.

65. Burke W, Keogh A, Maloney P, Delprado W, Bryant D, Spratt P. Transmission of sarcoidosis via cardiac transplantation. Lancet 1990; 336: 1579.

66. Hua Bing, Li Qing-di, Wang Fu-min, Ai Cheng-xu, Luo Wei-ci. Borrelia burgdorferi infection may be the cause of sarcoidosis. Chin Med J 1992; 105: 560-563.

67. Jacob F. Could Borrelia burgdorferi be a causal agent of sarcoidosis. Med Hypotheses 1989; 30: 241-243.

68. Martens H, Zöllner B, Zissel G, Burdon D, Schlaak M, Müller-Quernheim J. Anti-Borrelia burgdorferi immunoglobulin seroprevalence in pulmonary sarcoidosis. Eur Respir J 1997; 10: 1356-1358.

69. Puolakkainen M, Campbell LA, Kuo CC, Leinonen M, Grönhagen-Riska C, Saikku P. Serological response to Chlamydia pneumoniae in patients with sarcoidosis. $J$ Infection 1996; 33: 199-203.

70. Blasi F, Rizzato G, Gambacorta M, et al. Failure to detect the presence of Chlamydia pneumoniae in sarcoid pathology specimens. Eur Respir J 1997; 10: 2609-2611.

71. Haahr S, Munch M, Christensen T, Møller-Larsen A, 
Hvas J. Cluster of multiple sclerosis patients from Danish community. Lancet 1997; 349: 923.

72. Johnson BA, Duncan SR, Ohori NP, et al. Recurrence of sarcoidosis in pulmonary allograft recipients. Am Rev Respir Dis 1993; 148: 1373-1377.

73. Heatly T, Sekela M, Berger R. Single lung transplantation involving a donor with documented pulmonary sarcoidosis. J Heart Lung Transplant 1994; 13: 720-723.

74. Muller C, Briegel J, Haller M, et al. Sarcoidosis recurrence following lung transplantation. Transplantation 1996; 61: 1117-1119.

75. Anderson B, Sims K, Regnery R, et al. Detection of Rochalimaea henselae DNA in specimens from cat scratch disease patients by PCR. J Clin Microbiol 1994; 32: 942948.

76. Relman DA, Schmidt TM, MacDermott RP, Falkow S. Identification of the uncultured bacillus of whipple's disease. N Engl J Med 1990; 327: 293-301.

77. Williams R, Nickerson D. Skin reactions in sarcoid. Proc Soc Exp Biol Med 1935; 33: 402-405.

78. Kveim A. En ny og spesifik kutan-reakjon ved Boecks sarcoid. (Preliminary report on new and specific cutaneous reaction in Boecks sarcoid.) Nord Med 1941; 9: 1969-1972.

79. Chase MW. The preparation and standardization of Kveim testing antigen. Am Rev Respir Dis 1961; 84: 86-88.

80. Siltzbach L. The Kveim test in sarcoidosis. JAMA 1961; 178: 476-482.

81. Lyons D, Donald S, Mitchell D, Asherson G. Chemical inactivation of the Kveim reagent. Respiration 1992; 59: 22-26.

82. Lindahl M, Andersson O, Ripe E, Holm G. Stimulation of bronchoalveolar lavage (BAL) and blood lymphocytes by Kveim antigen, tuberculin and concanavalin A in sarcoidosis. Br J Dis Chest 1988; 82: 386-393.

83. Mandell G, Sullivan G, Siltzbach L, Suratt P. In vitro culture of leukocytes from patients with sarcoidosis: in search of an "in vitro Kveim Test". Virchows Arch (Cell Pathol) 1981; 35: 201-205.

84. Reutgen H, Eckert H, Christ R. Der Kveimtest in der Sarkoidosediagnostik. (The Kveim test in the diagnosis of sarcoidosis.) Z Erkr Atmungsorgane 1988; 170: 306-313.

85. Ishioka S, Fujihara M, Takaishi M, Yamakido M, Hosoda Y. Anti-Kveim monoclonal antibody - new monoclonal antibody reacting to epithelioid cells in sarcoid granulomas. Chest 1990; 98: 1255-1258.

86. Zissel G, Richter E, Kataria YP, Homolka J, Schlaak M, Müller-Quernheim J. Analysis of the Kveim-Siltzbachtest-reagent for bacterial DNA. Sarcoidosis Vasc Diff Lung Dis 1997; 14: 15.

87. Rook GWA, Stanford JL. Slow bacterial infections or autoimmunity? Immunol Today 1992; 13: 160-164.

88. Müller-Quernheim J, Saltini C, Sondermeyer P, Crystal RG. Compartmentalized activation of the interleukin-2 gene by lung T-lymphocytes in active pulmonary sarcoidosis. J Immunol 1986; 137: 3475-3483.

89. Klein J, Horn T, Forman J, Silver R, Tierstein A, Moller D. Selection of oligoclonal V $\beta$-specific $T$ cells in the intradermal response to Kveim-Siltzbach reagent in individuals with sarcoidosis. J Immunol 1995; 154: 1450-1460.

90. Cohn ZA, Fedorko ME, Hirsch JG, Morse SI, Siltzbach LE. The distribution of Kveim activity in subcellular fractions from sarcoid lymph nodes. In: Turiaf J, Chabot J, eds. Proceedings of the 4th International Conference on Sarcoidosis, La Sarkoidose. Paris, Masson \& Co., 1976; pp. 141-149.

91. Armbruster C, Dekan G, Hovorka A. Granulomatous pneumonitis and mediastinal lymphadenopathy due to photocopier toner dust. Lancet 1996; 348: 690.

92. Segal BM, Klinman DM, Shevach EM. Microbial products induce autoimmune disease by an IL-12-dependent pathway. J Immunol 1997; 158: 5087-5090.

93. Mitchell DN, Scadding JN. Sarcoidosis. Am Rev Respir Dis 1974; 110: 774-802.

94. Konietzko N, Faupel-Bauer B, Kraft J. Die Atemwege bei Sarkoidose. Dtsch Med Wochenschr 1987; 112: 1772-1778.

95. Meier-Sydow J, Gebhardt T, Kronenberger H, et al. Diffuse pulmonary fibrosis with airflow obstruction - clinical entities and classification. Prax Klin Pneumol 1983; 37: 335-341.

96. Nowak D, Kanzow G, Magnussen H. Patienten mit Sarkoidose haben gehäuft eine bronchiale Hyperreaktivität. Pneumologie 1990; 44: 572-573.

97. Bechtel J, Starr T III, Dantzker D, Bower J. Airway hyperreactivity in patients with sarcoidosis. Am Rev Respir Dis 1981; 124: 759-761.

98. Cole S, Johnson K, Ward P. Pathology of sarcoidosis, granulomatous vasculitis, and other idiopathic granulomatous diseases of the lung. In: Fanburg B, ed. Sarcoidosis and Other Granulomatous Diseases of the Lung. Basel, Dekker, 1983; pp. 149-202.

99. Mitchell D, Scadding J, Heard B, Hinson K. Sarcoidosis: histopathological definition and clinical diagnosis. J Clin Pathol 1977; 30: 395-408.

100. Daly PD, O'Brian DS, Robinson I, Prichard JS. Hodgkin's disease with a granulomatous pulmonary presentation mimicking sarcoidosis. Thorax 1988; 43: 407-409.

101. du Bois RM. Mimics of sarcoidosis, extrinsic allergic alveolitis. Sarcoidosis 1991; 8: 85-88.

102. James DG. Mimics of sarcoidosis, oro-facial granulomatosis (Melkersson-Rosenthal Syndrome). Sarcoidosis 1991; 8: 84.

103. Brincker $\mathrm{H}$. The sarcoidosis-lymphoma syndrome. $\mathrm{Br} J$ Cancer 1986; 54: 467-473.

104. Newman LS, Kreiss K. Nonoccupational beryllium disease masquerading as sarcoidosis: identification by blood lymphocyte proliferative response to beryllium. Am Rev Respir Dis 1992; 145: 1212-1214.

105. Müller-Quernheim J, Zissel G, Schopf R, Vollmer E, Schlaak M. Differentialdiagnose Berylliose/Sarkoidose bei einem Zahntechniker. Dtsch Med Wochenschr 1996; 121: 1462-1466.

106. Kent DC, Houk VN, Elliott RC, Sokolowski JW, Baker JH, Sorensen K. The definitive evaluation of sarcoidosis. Am Rev Respir Dis 1970; 101: 721-727.

107. Hunninghake GW, Gilbert S, Pueringer R, et al. Outcome of the treatment of sarcoidosis. Am J Respir Crit Care Med 1994; 149: 893-898.

108. Sones M, Israel H. Course and prognosis of sarcoidosis. Am J Med 1960; 29: 84-93.

109. Stone D, Schwartz A. A long term study of sarcoid and its modification by steroid therapy. Lung function and other factors of prognosis. Am J Med 1966; 41: 528-540.

110. Car BD, Meloni F, Luisetti M, Semenzato G, GialdroniGrassi G, Walz A. Elevated IL-8 and MCP-1 in the bronchoalveolar lavage fluid of patients with idiopathic pulmonary fibrosis and pulmonary sarcoidosis. Am J Respir Crit Care Med 1994; 149: 655-659.

111. Standiford T, Rolfe M, Kunkel S, et al. Macrophage inflammatory protein- $1 \alpha$ expression in interstitial lung disease. J Immunol 1993; 151: 2852-2863.

112. Ming JW, Bersani L, Mantovani A. Tumor necrosis factor is chemotactic for monocytes and polymorphonuclear leukocytes. J Immunol 1987; 138: 1469-1474. 
113. Kiemle-Kallee J, Kreipe H, Radzun HJ, et al. Alveolar macrophages in idiopathic pulmonary fibrosis display a more monocyte-like immunophenotype and an increased release of free oxygen radicals. Eur Respir J 1991; 4: 400-406.

114. Striz I, Wang J, Teschler H, Sorg C, Costabel U. Phenotypic markers of alveolar macrophage maturation in pulmonary sarcoidosis. Lung 1993; 171: 293-303.

115. Pforte A, Gerth C, Voss A, et al. Proliferating alveolar macrophages in BAL and lung function changes in interstitial lung. Eur Respir J 1993; 6: 951-955.

116. Petrek M, Pantelidis P, Southcott AM, et al. The source and role of RANTES in interstitial lung disease. Eur Respir J 1997; 10: 1207-1216.

117. Hunninghake GW. Release of interleukin-1 by alveolar macrophages of patients with active pulmonary sarcoidosis. Am Rev Respir Dis 1984; 129: 569-572.

118. Müller-Quernheim J, Pfeifer S, Männel D, Strausz J, Ferlinz R. Lung restricted activation of the alveolar macrophage/monocyte system in pulmonary sarcoidosis. Am Rev Respir Dis 1992; 145: 187-192.

119. Strausz J, Männel D, Pfeifer S, Borkowski A, Ferlinz R, Müller-Quernheim J. Spontaneous monokine release by alveolar macrophages in chronic sarcoidosis. Int Archs Allergy Appl Immun 1991; 96: 68-75.

120. Homolka J, Müller-Quernheim J. Increased interleukin 6 production by bronchoalveolar lavage cells in patients with active sarcoidosis. Lung 1993; 171: 173-183.

121. Steffen M, Petersen J, Oldigs M, et al. Increased secretion of tumor necrosis factor-alpha, interleukin-1-beta, and interleukin- 6 by alveolar macrophages from patients with sarcoidosis. Chest 1993; 91: 939-949.

122. Kunkel SL, Remick DG, Strieter RM, Larrick JW. Mechanisms that regulate the production and effects of tumor necrosis factor- $\alpha$. Crit Rev Immunol 1989; 9: 93-117.

123. De Rose V, Trentin L, Crivellari MT, et al. Release of prostaglandin $\mathrm{E}_{2}$ and leukotriene $\mathrm{B} 4$ by alveolar macrophages from patients with sarcoidosis. Thorax 1997; 52: 76-83.

124. Foley N, Lambert C, McNicol M, Johnson N, Rook GAW. An inhibitor of the toxicity of tumor necrosis factor in the serum of patients with sarcoidosis, tuberculosis and Crohn's disease. Clin Exp Immunol 1990; 80: 395-399.

125. Seckinger P, Zhang JH, Hauptmann B, Dayer JM. Characterisation of tumor necrosis factor- $\alpha$ (TNF- $\alpha$ ) inhibitor. Evidence of immunological cross-reactivity with the TNF receptor. Proc Natl Acad Sci USA 1990; 87: 5188-5192.

126. Walker C, Bauer W, Braun R, et al. Activated T cells and cytokines in bronchoalveolar lavages from patients with various lung diseases associated with eosinophilia. Am J Respir Crit Care Med 1994; 150: 1038-1048.

127. Nakayama T, Hashimoto E, Amemiya E, Horie T. Elevation of plasma-soluble tumor necrosis factor receptors (TNF-R) in sarcoidosis. Clin Exp Immunol 1997; 104: 318-324.

128. Beutler B, Cerami A. Cachectin: more than a tumor necrosis factor. $N$ Engl J Med 1987; 316: 379-385.

129. Lem VM, Lipscomb MF, Weissler JC, et al. Bronchoalveolar cells from sarcoid patients demonstrate enhanced antigen presentation. J Immunol 1985; 135: 1766-1771.

130. Venet A, Hance AJ, Saltini C, Robinson BWS, Crystal RG. Enhanced alveolar macrophage-mediated antigeninduced T lymphocyte proliferation in sarcoidosis. J Clin Invest 1985; 75: 293-301.

131. Zissel G, Ernst M, Schlaak M, Müller-Quernheim J. Accessory function of alveolar macrophages from patients with sarcoidosis and other granulomatous and non-granulomatous lung diseases. J Invest Med 1997; 45: 75-86.

132. Nabavi N, Freeman GJ, Gault A, Godfrey D, Nadler LM, Glimcher LH. Signalling through the MHC class II cytoplasmic domain is required for antigen presentation and induces B7 expression. Nature 1992; 360: 266-268.

133. Zissel G, Aulitzky W, Lorenz J, Huber C, Müller-Quernheim J. Induction of accessory cell function of human alveolar macrophages by inhalation of human natural interleukin-2. Cancer Immunol Immun 1996; 42: 122-126.

134. Reiser H, Stadecker MJ. Costimulatory B7 molecules in the pathogenesis of infectious and autoimmune diseases. N Engl J Med 1996; 335: 1369-1377.

135. Costabel U, Bross KJ, Rühle KH, Lohr GW, Matthys H. Ia-like antigens on T-cells and their subpopulations in pulmonary sarcoidosis and hypersensitivity pneumonitis. Am Rev Respir Dis 1985; 131: 337-342.

136. Saltini C, Hemler ME, Crystal RG. T lymphocytes compartmentalized on the epithelial surface of the lower respiratory tract express the very late activation antigen complex VLA-1. Clin Immunol Immunopathol 1988; 46: 221-233.

137. Müller-Quernheim J, Krönke M, Strausz J, Schykowski M, Ferlinz R. Interleukin-2 receptor gene expression by bronchoalveolar lavage lymphocytes in pulmonary sarcoidosis. Am Rev Respir Dis 1989; 140: 82-88.

138. duBois RM, Kirby M, Balbi B, Saltini C, Crystal RG. Tlymphocytes that accumulate in the lung in sarcoidosis have evidence of recent stimulation of the T-cell antigen receptor. Am Rev Respir Dis 1992; 145: 1205-1211.

139. Kita S, Tsuda T, Sugisaki K, Miyazaki E, Matsumoto T. Characterization of distribution of $\mathrm{T}$ lymphocyte subsets and activated $\mathrm{T}$ lymphocytes infiltrating into sarcoid lesions. Intern Med 1995; 34: 847-855.

140. Modlin RL, Hofman FM, Meyer PR, Sharma OP, Taylor CR, Rea TH. In situ demonstration of T lymphocyte subsets in granulomatous inflammation: leprosy, rhinoscleroma and sarcoidosis. Clin Exp Immunol 1983; 51: 430-438.

141. Pinkston P, Bitterman PB, Crystal RG. Spontaneous release of interleukin-2 by lung T-lymphocytes in active pulmonary sarcoidosis. N Engl J Med 1983; 308: 793-800.

142. Hunninghake GW, Bedell GN, Zavala DC, Monick M, Brady M. Role of interleukin-2 release by lung T-cells in active pulmonary sarcoidosis. Am Rev Respir Dis 1983; 128: 634-636.

143. Devergne O, Emilie D, Peuchmaur M, Crevon MC, D'Agay MF, Galanaud P. Production of cytokines in sarcoid lymph nodes: preferential expression of interleukin$1 \beta$ and interferon- $\gamma$ genes. Hum Pathol 1992; 23: 317323.

144. Asano M, Minagawa T, Ohmichi M, Hiraga Y. Detection of endogenous cytokines in sera or in lymph nodes obtained from patients with sarcoidosis. Clin Exp Immunol 1991; 84: 92-96.

145. Saltini C, Spurzem JR, Lee JJ, Pinkston P, Crystal RG. Spontaneous release of interleukin-2 by lung T-lymphocytes in active pulmonary sarcoidosis is primarily from the Leu3+ DR+ T-cell subset. J Clin Invest 1986; 77 : 1962-1970.

146. Paine RI, Mody CH, Chawis A, Spahr MA, Turka LA, Toews GB. Alveolar epithelial cells block lymphocyte proliferation in vitro without inhibiting activation. Am J Respir Cell Mol Biol 1991; 5: 221-229.

147. Strauchen JA, Breakstone BA. IL-2 receptor expression in human lymphoid lesions. Am J Pathol 1987; 126: 506512.

148. Holter J, Park H, Sjoerdsma K, Kataria Y. Nonviable 
autologous bronchoalveolar lavage cell preparations induce intradermal epithelioid cell granulomas in sarcoidosis patients. Am Rev Respir Dis 1992; 145: 864-871.

149. Moller DR, Konishi K, Kirby M, Balbi B, Crystal RG. Bias toward use of a specific T-cell receptor $\beta$-chain variable region in a subgroup of individuals with sarcoidosis. J Clin Invest 1988; 82: 1183-1191.

150. Grunewald J, Olerup O, Persson U, Öhrn BM, Wigzell H, Eklund A. T-cell receptor variable region gene usage by CD4+ and CD8+ T cells in bronchoalveolar lavage fluid and peripheral blood of sarcoidosis patients. Proc Natl Acad Sci USA 1994; 91: 4965-4969.

151. Forman J, Klein J, Silver R, Liu M, Greenlee B, Moller D. Selective activation and accumulation of oligoclonal $\mathrm{V} \beta$-specific $\mathrm{T}$ cells in active pulmonary sarcoidosis. $J$ Clin Invest 1994; 94: 1533-1542.

152. Tamura N, Moller D, Balbi B, Crystal R. Preferential usage of the T-cell antigen receptor beta-chain constant region $\mathrm{C}$ beta 1 element by lung T-lymphocytes of patients with pulmonary sarcoidosis. Am Rev Respir Dis 1991; 143: 635-639.

153. Zissel G, Bäumer I, Fleischer B, Schlaak M, MüllerQuernheim J. TCR V beta families in T cell clones from sarcoid lung parenchyma, BAL and blood. Am J Respir Crit Care Med 1997; 156: 1593-1600.

154. Bellocq A, Lecossier D, Pierre-Audigier C, Tazi A, Valeyre D, Hance AJ. T cell receptor repertoire of T lymphocytes recovered from the lung and blood of patients with sarcoidosis. Am J Respir Crit Care Med 1994; 149: 646-654.

155. Dohi M, Yamamoto K, Masuko K, et al. Accumulation of multiple $\mathrm{T}$ cell clonotypes in lungs of healthy individuals and patients with pulmonary sarcoidosis. J Immunol 1994; 152: 1983-1988.

156. Silver RF, Crystal RG, Moller DR. Limited heterogeneity of biased T-cell receptor $\mathrm{V} \beta$ gene usage in lung but not blood $\mathrm{T}$ cells in active pulmonary sarcoidosis. Immunology 1996; 88: 516-523.

157. Gorski J, Yassai M, Zhu X, Kissella B, Keevr C, Flomenberg N. Circulating $\mathrm{T}$ cell repertoire complexity in normal individuals and bone marrow recipients analyzed by CDR3 size spectratyping. J Immunol 1994; 152: 51095119.

158. Burastero SE, Borgonovo B, Gaffi D, et al. The repertoire of T-lymphocytes recovered by bronchoalveolar lavage from healthy nonsmokers. Eur Respir J 1996; 9: 319-327.

159. Saltini C, Winestock K, Kirby M, Pinkston P, Crystal RG. Maintenance of alveolitis in patients with chronic beryllium disease by beryllium-specific helper T cells. $N$ Engl J Med 1989; 320: 1103-1109.

160. Wahlström J, Berlin M, Lundgren R, et al. Lung and blood T-cell receptor repertoire in extrinsic allergic alveolitis. Eur Respir J 1997; 10: 772-779.

161. Grunewald J, Hultman T, Bucht A, Eklund A, Wigzell H. Restricted usage of $\mathrm{T}$ cell receptor $\mathrm{V}$ alpha/J alpha gene segments with different nucleotide but identical amino acid sequences in HLA-DR3+ sarcoidosis patients. Mol Med 1995; 1: 287-296.

162. Mosmann TR, Cherwinski H, Bond MW, Giedlin MA, Coffman RL. Two types of murine helper T cell clone. I. Definition according to profiles of lymphokine activities and secreted proteins. J Immunol 1986; 136: 2348-2357.

163. Fiorentino DF, Zlotniu A, Mosmann TR, Howard M. O'Garra A. IL-10 inhibits cytokine production by activated macrophages. J Immunol 1991; 147: 3815-3822.

164. Romagnani S. Th1 and Th2 in human diseases. Clin Immunol Immunopathol 1996; 80: 225-235.
165. Robinson BWS, McLemore T, Crystal RG. $\gamma$-Interferon is spontaneously released by alveolar macrophages and lung T-lymphocytes in patients with pulmonary sarcoidosis. J Clin Invest 1985; 75: 1488-1495.

166. Hoshino $\mathrm{T}$, Itoh $\mathrm{K}$, Gouhara $\mathrm{R}$, et al. Spontaneous production of various cytokines except IL4 from CD4+ T cells in the affected organs of sarcoidosis patients. Clin Exp Immunol 1995; 102: 399-405.

167. Minshall EM, Tsicopoulos A, Yasruel Z, et al. Cytokine mRNA gene expression in active and nonactive pulmonary sarcoidosis. Eur Respir J 1997; 10: 2034-2039.

168. Bäumer I, Zissel G, Schlaak M, Müller-Quernheim J. Th1/Th2 cell distribution in pulmonary sarcoidosis. Am J Respir Cell Mol Biol 1997; 16: 171-177.

169. Grutters JC, Drent M, van Velzen-Blad H, van den Bosch JMM. Improvement of bronchial asthma during an episode of active sarcoidosis. A case report. Am J Respir Crit Care Med 1996; 153: A282.

170. Balbi B, Moller DR, Kirby M, Holrody KJ, Crystal RG. Increased numbers of T-lymphocytes with $\gamma \delta$-positive antigen receptors in a subgroup of individuals with pulmonary sarcoidosis. J Clin Invest 1990; 85: 1353-1361.

171. Pfeifer S, Müller-Quernheim J. Subtypisierung von T-Lymphozyten bei Sarkoidose. Pneumologie 1994; 48: 427-432.

172. Raulf M, Liebers V, Steppert C, Baur X. Increased $\gamma / \delta$ positive T-cells in blood and bronchoalveolar lavage of patients with sarcoidosis and hypersensitivity pneumonitis. Eur Respir J 1994; 7: 140-147.

173. Balbi B, Valle M, Oddera S, et al. T-lymphocytes with $\gamma \delta+\mathrm{V} \delta 2+$ antigen receptors are present in increased proportions in a fraction of patients with tuberculosis or with sarcoidosis. Am Rev Respir Dis 1993; 148: 1685-1690.

174. Forrester J, Newman L, Wang Y, King T, Kotzin B. Clonal expansion of lung V $\delta 1+$ cells in pulmonary sarcoidosis. J Clin Invest 1993; 91: 292-300.

175. Tazi A, Fajac I, Soler P, Valeyre D, Battesti JP, Hance AJ. $\gamma / \delta$ T-lymphocytes are not increased in number in granulomatous lesions of patients with tuberculosis or sarcoidosis. Am Rev Respir Dis 1991; 144: 1373-1376.

176. Jenkins R, Nikaein A, Zimmermann A, Meek A, Lipsky P. T cell receptor $\mathrm{V} \beta$ gene bias in rheumatoid arthritis. $J$ Clin Invest 1993; 92: 2688-2701.

177. Posnett DN, Schmelkin I, Burton DA, August A, McGrath $\mathrm{H}$, Mayer LF. T cell antigen receptor $\mathrm{V}$ gene usage. Increases in V $\beta 8+\mathrm{T}$-cells in Crohn's disease. $J$ Clin Invest 1990; 85: 1770-1776.

178. Newman LS. To Be2+ or not to Be2+: immunogenetics and occupational exposure (Comment). Science 1993; 262: 197-198.

179. Kubicka-Mulanyi M, Kremer J, Rottmann N, et al. Murine systemic autoimmune disease induced by mercuric chloride: T helper cells reacting to self proteins. Int Arch Allergy Immunol 1996; 109: 11-20.

180. Kubicka-Muranyi M, Griem P, Lübben B, Rottmann N, Lührmann R, Gleichmann E. Mercuric-chloride-induced autoimmunity in mice involves up-regulated presentation by spleen cells of altered and unaltered nucleolar self antigen. Int Arch Allergy Immunol 1995; 108: 1-10.

181. Kunkel SL, Chensue SW, Strieter RM, Lynch JP, Remick DG. Cellular and molecular aspects of granulomatous inflammation. Am J Respir Cell Mol Biol 1989; 1: 439447.

182. Subramanian G, Kazura JW, Pearlman E, Jia X, Malhtra I, King CL. B7-2 requirement for helminth-induced granuloma formation and CD4 Type $2 \mathrm{~T}$ helper cell cytokine expression. J Immunol 1997; 158: 5914-5920.

183. Singh RP, Patarca R, Schwartz J, Singh P, Cantor H. De- 
finition of a specific interaction between the early $\mathrm{T}$ lymphocyte activation 1 (Eta-1) protein and murine macrophages in vitro and its effect upon macrophages in vivo. J Exp Med 1990; 171: 1931-1942.

184. Nau GJ, Guilfoile P, Chupp GL, et al. A chemoattractant cytokine associated with granulomas in tuberculosis and silicosis. Proc Natl Acad Sci USA 1997; 94: 6414-6419.

185. Chensue SW, Otterness IG, Higashi GI, Shmyr Forsch C, Kunkel SL. Monokine production by hypersensitivity (Shistosoma mansoni egg) and foreign body (Sephadex bead)-type granuloma macrophages. Evidence for sequential production of IL-1 and tumor necrosis factor. $J$ Immunol 1989; 142: 1281-1286.

186. Kindler V, Sappino A, Grau G, Piguet P, Vassalli P. The inducing role of tumor necrosis factor in the development of bactericidal granulomas during BCG infection. Cell 1989; 56: 731-740.

187. Gudmundsson G, Hunninghake GW. Interferon- $\gamma$ is necessary for the expression of hypersensitivity pneumonitis. J Clin Invest 1997; 99: 2386-2390.

188. Kemp M, Theander TG, Kharazmi A. The contrasting roles of CD4+ $\mathrm{T}$ cells in the intracellular infections in humans: leishmaniasis as an example. Immunol Today 1996; 17: 13-16.

189. Chensue SW, Warmington K, Ruth JH, Lukacs N, Kunkel SL. Mycobacterial and schistosomal antigen-elicited granuloma formation in IFN-gamma and IL-4 knockout mice: analysis of local and regional cytokine and chemokine networks. J Immunol 1997; 159: 356-573.

190. Bergeron A, Bonay M, Kambouchner M, et al. Cytokine patterns in tuberculous and sarcoid granulomas: correlations with histopathologic features of the granulomatous response. J Immunol 1997; 159: 303-443.

191. Smith RE, Strieter RM, Zhang K, Phan SH, Standiford TJ, Lukacs NW. A role for C-C chemokines in fibrotic lung disease. J Leukoc Biol 1995; 57: 782-787.

192. Rolfe MW, Kunkel SL, Standiford TJ, et al. Pulmonary fibroblast expression of interleukin-8: a model for alveolar macrophage-derived cytokine networking. Am J Respir Cell Mol Biol 1991; 5: 493-501.

193. Moseley PL, Hemken C, Monick MM, Nugent KM, Hunninghake GW. Interferon and growth factor activity for human lung fibroblasts: release from bronchoalveolar cells from patients with active sarcoidosis. Chest 1986; 89: 657-662.

194. Bjermer L, Eklund A, Blaschke E. Bronchoalveolar lavage fibronectin in patients with sarcoidosis: correlation to hyaluronan and disease activity. Eur Respir J 1991; 4: 965-971.

195. Mornex JF, Leroux C, Greenland T, Ecochard D. From granuloma to fibrosis in interstitial lung disease: molecular and cellular interactions. Eur Respir J 1994; 7: 779-785.

196. Pohl WR, Thompson AB, Köhn H, et al. Serum procollagen III peptide levels in subjects with sarcoidosis. A 5-year follow-up study. Am Rev Respir Dis 1992; 145: 412-417.

197. O'Connor CM, Ward K, van Breda A, McIlgorm A, FitzGerald MX. Type 3 procollagen peptide in bronchoalveolar lavage fluid. Poor indicator of course and prognosis in sarcoidosis. Chest 1989; 96: 339-344.

198. Perez RL, Duncan A, Hunter RL, Staton GL. Elevated D dimer in the lungs and blood of patients with sarcoidosis. Chest 1993; 103: 1100-1106.

199. Schaberg T, Orzechowski K, Oesterling C, Lode H, Schuppan D. Simultaneous measurement of collagen type-VI-related antigen and procollagen type-N-propeptide levels in bronchoalveolar lavage. Eur Respir J 1994;
7: 1221-1226.

200. Bensadoun ES, Burke AK, Hogg JC, Roberts CR. Proteoglycan deposition in pulmonary fibrosis. Am J Respir Crit Care Med 1996; 154: 1819-1828.

201. Lammi L, Kinnula V, Lahde S, et al. Propeptide levels of type III and type I procollagen in the serum and bronchoalveolar lavage fluid of patients with pulmonary sarcoidosis. Eur Respir J 1997; 10: 2725-2730.

202. Moller DR, Forman JD, Liu MC, et al. Enhanced ex-pression of IL-12 associated with Th1 cytokine profiles in active pulmonary sarcoidosis. J Immunol 1996; 156: 4952-4960.

203. Pinkston P, Saltini C, Müller-Quernheim J, Crystal RG. Corticosteroid therapy suppresses spontaneous interleukin-2 release and spontaneous proliferation of lung T-lymphocytes of patients with active pulmonary sarcoidosis. $J$ Immunol 1987; 139: 755-760.

204. Center DM, Kornfeld H, Cruikshank WW. Interleukin 16 and its function as a CD4 ligand. Immunol Today 1996; 17: 476-481.

205. Gaede KI, Zissel G, Schwulera U, et al. Spontaneous and interleukin-2-modulated cytokine release of bronchoalveolar cells in pulmonary malignancy. Eur Cytokine Netw 1997; 8: 395-400.

206. Müller-Quernheim J, Pfeifer S, Kienast K, Zissel G. Spontaneous interleukin-2 release of bronchoalveolar lavage cells in sarcoidosis is a co-determinator of prognosis. Lung 1996; 174: 243-253.

207. Girgis R, Basha M, Maliarik M, Popovich J Jr, Iannuzzi $\mathrm{M}$. Cytokines in the bronchoalveolar lavage fluid of patients with active pulmonary sarcoidosis. Am J Respir Crit Care Med 1995; 152: 71-75.

208. Takizawa H, Satoh M, Okazaki H, et al. Increased IL-6 and IL-8 in bronchoalveolar lavage fluids (BALF) from patients with sarcoidosis: correlation with the clinical parameters. Clin Exp Immunol 1997; 107: 175-181.

209. Ziegenhagen MW, Schrum S, Zissel G, Zipfel PF, Schlaak M, Müller-Quernheim J. Increased expression of proinflammatory chemokines in bronchoalveolar lavage cells of patients with progressing idiopathic pulmonary fibrosis and sarcoidosis. J Invest Med 1998; 46: 223-231.

210. Otte HG, Hartig C, Stadler R. Sarkoidose bei Interferonalpha-Therapie. (Sarcoidosis in interferon-alpha therapy.) Hautarzt 1997; 48: 482-487.

211. Bansal AS, Bruce J, Hogan PG, Allen RK. An assessment of peripheral immunity in patients with sarcoidosis using measurements of serum vitamin D3, cytokines and soluble CD23. Clin Exp Immunol 1997; 110: 92-97.

212. Prior C, Knight RA, Herold M, Ott G, Spiteri MA. Pulmonary sarcoidosis: patterns of cytokine release in vitro. Eur Respir J 1996; 9: 47-53.

213. Prior C, Haslam P. Increased levels of serum interferon- $\gamma$ in pulmonary sarcoidosis and relationship with response to corticosteroid therapy. Am Rev Respir Dis 1991; 143: 53-60.

214. Swider C, Laba A, Moniewska A, Gerdes J, Flad HD, Lange A. Presence of mRNA for interferon-gamma (IFNgamma) in blood mononuclear cells is associated with an active stage I sarcoidosis. Clin Exp Immunol 1995; 100: 401-405.

215. Westermann J, Persin S, Matyas J, van der Meide P, Pabst R. Migration of so-called naive and memory $T$ lymphocytes from blood to lymph in the rat. The influence of IFN-gamma on the circulation pattern. J Immunol 1994; 152: $1744-1750$.

216. Westermann J, Pabst R. Lymphocyte subsets in the blood: a diagnostic window on the lymphoid system? Immunol 
Today 1990; 11: 406-410.

217. Sugiyama Y, Kasahara T, Mukaida N, Matsushima K, Kitamura S. Chemokines in bronchoalveolar lavage fluid in summer-type hypersensitivity pneumonitis. Eur Respir J 1995; 8: 1084-1090.

218. Iida K, Kadota J, Kawakami K, Matsubara Y, Shirai R, Kohno S. Analysis of T cell subsets and beta chemokines in patients with pulmonary sarcoidosis. Thorax 1997; 52: 431-437.

219. Keane MP, Arenberg DA, Lynch JPr, et al. The CXC chemokines, IL-8 and IP-10, regulate angiogenic activity in idiopathic pulmonary fibrosis. J Immunol 1997; 159: 1437-1443.

220. Bäumer I, Zissel G, Schlaak M, Müller-Quernheim J. Soluble intercellular adhesion molecule 1 (sICAM-1) in bronchoalveolar lavage (BAL) cell cultures and in the circulation of patients with tuberculosis, hypersensitivity pneumonitis and sarcoidosis. Eur J Med Res 1998, 3: 288-294.

221. Müller-Quernheim J, Pfeifer S, Strausz J, Ferlinz R. Correlation of clinical and immunological parameters of the inflammatory activity of pulmonary sarcoidosis. Am Rev Respir Dis 1991; 144: 1322-1329.

222. Guede KI, Fitschen J, Ernst M, Schlaan M, MüllerQuernheim J. Expression and shedding of tumor necrosis factor receptors in bronchoalveolar cells. Am J Respir Crit Care Med 1998; 157: A436.

223. Nakayama T, Hashimoto S, Amemiya E, Horie T. Elevation of plasma-soluble tumour necrosis factor receptors (TNF-R) in sarcoidosis. Clin Exp Immunol 1996; 104: 318-324.

224. Bäumer I, Zissel G, Schlaak M, Müller-Quernheim J. Shed sICAM-1 molecules in BAL cell supernatants and serum of patients with pulmonary sarcoidosis. Lung 1997; 175: 105-116.

225. Pforte A, Schiessler A, Kressenstein S, et al. ICAM-1 expression on alveolar macrophages and in serum of sarcoidosis patients. J Clin Lab Immunol 1995; 46: 125-135.

226. Ziegenhagen MW, Fitschen J, Martinet N, Schlaan M, Müller-Quernheim J. Serum level of soluble tumor necrosis factor Type II reflects disease activity in sarcoidosis. Am J Respir Crit Care Med 1998; 157: A29.

227. Shijubo N, Imai K, Shigehara K, et al. Soluble intercellular adhesion molecule-1 (ICAM1) in sera and bronchoalveolar lavage fluid of patients with idiopathic pulmonary fibrosis and pulmonary sarcoidosis. Clin Exp Immunol 1994; 95: 156-161.

228. Valeyre D, Soler P, Basset G, et al. Glucose, K+, and albumin concentrations in the alveolar milieu of normal humans and pulmonary sarcoidosis patients. Am Rev Respir Dis 1991; 143: 1096-1101.

229. Planès C, Valeyre D, Loiseau A, Bernaudin J, Soler P. Ultrastructural alterations of the air-blood barrier in sarcoidosis and hypersensitivity pneumonitis and their relation to lung histopathology. Am J Respir Crit Care Med 1994; 150: 1067-1074.

230. Rothlein R, Mainolfi E, Czajkowski M, Marlin S. A form of circulating ICAM-1 in human serum. J Immunol 1991; 147: 3788-3793.

231. Berghella AM, Pellegrini P, Del Beato T, et al. The significance of an increase in soluble interleukin-2 receptor level in colorectal cancer and its biological regulating role in the physiological switching of the immune response cytokine network from $\mathrm{TH} 1$ to $\mathrm{TH} 2$ and back. Cancer Immunol Immunother 1998; 45: 241-249.

232. Piguet $\mathrm{P}$, Vesin $\mathrm{C}$. Treatment by human recombinant soluble TNF receptor of pulmonary fibrosis induced by bleo- mycin or silica in mice. Eur Respir J 1994; 7: 515-518.

233. Kline JN, Schwartz D, Monick MM, Floerchinger CS, Hunninghake GW. Relative release of interleukin-1b and interleukin-1 receptor antagonist by alveolar macrophages. A study in asbestos-induced lung disease, sarcoidosis, and idiopathic pulmonary fibrosis. Chest 1993; 104: 4753.

234. Rolfe MW, Standiford TJ, Kunkel SL, et al. Interleukin-1 receptor antagonist expression in sarcoidosis. Am Rev Respir Dis 1993; 148: 1378-1384.

235. Ulich TR, Yin SM, Guo KZ, del Castillo J, Eisenberg SP, Thompson RC. The intratracheal administration of endotoxin and cytokines. III. The interleukin-1 (IL-1) receptor antagonist inhibits endotoxin- and IL-1-induced acute inflammation. Am J Pathol 1991; 138: 521-524.

236. Xing Z, Gauldie J, Cox G, et al. IL-6 is an antiinflammatory cytokine required for controlling local or systemic acute inflammatory responses. J Clin Invest 1998; 101: 311-320.

237. deWaal Malefyt R, Haanen J, Spits H, et al. Interleukin 10 (IL-10) and viral IL-10 strongly reduce antigenspecific human $\mathrm{T}$ cell proliferation by diminishing the antigen-presenting capacity of monocytes via downregulation of class II major histocompatibility complex expression. J Exp Med 1991; 174: 915-924.

238. Zissel G, Homolka J, Schlaak J, Schlaak M, Müller-Quernheim J. Anti-inflammatory cytokine release by alveolar macrophages in pulmonary sarcoidosis. Am J Respir Crit Care Med 1996; 154: 713-719.

239. Wahl SM, McCartney-Francis N, Mergenhagen S. Inflammatory and immunoregulatory roles of TGF- $\beta$. Immunol Today 1989; 10: 258-261.

240. Schmitt E, Höhn P, Hüls C, et al. T helper type 1 development of native $\mathrm{CD} 4+\mathrm{T}$ cells requires the coordinate action of interleukin-12 and interferon- $\gamma$ and is inhibited by transforming growth factor- $\beta$. Eur J Immunol 1994; 24: 793-798.

241. Koberda J, Grimm E, Moser R. Effect of anti-CD3/antiCD28/interleukin-2 stimulation of mononuclear cells on transforming growth factor $\beta$ inhibition of lymphokineactivated killer cell generation. J Cancer Res Clin Oncol 1993; 119: 131-136.

242. Begovich AB, Klitz W, Moonsamy PV, Van de Water J, Peltz G, Gershwin ME. Genes within the HLA class II region confer both predisposition and resistance to primary biliary cirrhosis. Tissue Antigens 1994; 43: 7177.

243. Begovich AB, Helmuth RC, Oksenberg JR, et al. HLADP beta and susceptibility to multiple sclerosis: an analysis of caucasoid and Japanese patient populations. Hum Immunol 1990; 28: 365-372.

244. Lenhart K, Kolek V, Bartova A. HLA antigens associated with sarcoidosis. Dis Markers 1990; 8: 23-29.

245. Berlin M, Fogdell-Hahn A, Olerup O, Eklund A, Grunewald J. HLA-DR predicts the prognosis in Scandinavian patients with pulmonary sarcoidosis. Am J Respir Crit Care Med 1997; 156: 1601-1605.

246. Grunewald J, Shigematsu M, Nagai S, Mikuniya T, Izumi T, Eklund A. T-cell receptor V gene expression in HLAtyped Japanese patients with pulmonary sarcoidosis. Am J Respir Crit Care Med 1995; 151: 151-156.

247. McGuire W, Hill A, Allsopp C, Greenwood B, Kwiatkowski D. Variation in the TNF- $\alpha$ promoter region associated with susceptibility to cerebral malaria. Nature 1994; 371: 508-511.

248. Cabrera M, Shaw MA, Sharples C, et al. Polymorphism in tumor necrosis factor genes associated with mucocuta- 
neous leishmaniasis. J Exp Med 1995; 182: 1259-1264.

249. Huang SL, Su CH, Chang SC. Tumor necrosis factoralpha gene polymorphism in chronic bronchitis. Am J Respir Crit Care Med 1997; 156: 1436-1439.

250. Stüber F, Petersen M, Bokelmann F, Schade F. A genomic polymorphism within the TNF locus influences TNF plasma levels and outcome of patients with severe sepsis. Crit Care Med 1995; 24: 381-384.

251. Wilson AG, Symons JA, McDowell TL, McDevitt HO, Duff GW. Effects of a polymorphism in the human tumor necrosis factor alpha promoter on transcriptional activation. Proc Natl Acad Sci USA 1997; 94: 3195-3199.

252. Seitzer U, Swider C, Stuber F, et al. Tumour necrosis factor alpha promoter gene polymorphism in sarcoidosis. Cytokine 1997; 9: 787-790.

253. Hino T, Nakamura H, Shibata Y, Abe S, Kato S, Tomoike H. Elevated levels of type II soluble tumor necrosis factor receptors in the bronchoalveolar lavage fluids of patients with sarcoidosis. Lung 1997; 175: 187-193.

254. Agostini C, Zambello R, Sancetta R, et al. Expression of tumor necrosis factor-receptor superfamily members by lung $\mathrm{T}$ lymphocytes in interstitial lung disease. Am $J$ Respir Crit Care Med 1996; 153: 1359-1367.

255. Wilson AG, de Vries N, Pociot F, di Giovine FS, van der Putte LB, Duff GW. An allelic polymorphism within the human tumor necrosis factor alpha promoter region is strongly associated with HLA A1, B8, and DR3 alleles. $J$ Exp Med 1993; 177: 557-560.

256. Cox A, Gonzalez AM, Wilson AG, et al. Comparative analysis of the genetic associations of HLA-DR3 and tumour necrosis factor alpha with human IDDM. Diabetologia 1994; 37: 500-503.

257. Wilson AG, Gordon C, di Giovine FS, et al. A genetic association between systemic lupus erythematosus and tumor necrosis factor alpha. Eur J Immunol 1994; 24: 191-195.

258. Ishihara M, Ohno S, Ishida $\mathrm{T}$, et al. Molecular genetic studies of class II alleles in sarcoidosis. Tissue Antigens 1994; 43: 238-241.

259. Gill RG, Babcock SK, Lafferty KJ. A quantitative analysis of antigen-triggered lymphokine production by activated T cells. J Immunol 1987; 138: 1130-1136.

260. Suzuki K, Tamura N, Iwase A, Dambara T, Kira S. Prognostic value of Ia+ T lymphocytes in bronchoalveolar lavage fluid in pulmonary sarcoidosis. Am J Respir Crit Care Med 1996; 154: 707-712.

261. Drent M, van Velzen-Blad H, Diamant M, Hoogsteden HC, van den Bosch JMM. Relationship between presentation of sarcoidosis and T lymphocyte profile. A study in bronchoalveolar lavage fluid. Chest 1993; 104: 795800.

262. Ward K, O'Connor C, Odlum C, Fitzgerald MX. Prognostic value of bronchoalveolar lavage in sarcoidosis: the critical influence of disease presentation. Thorax 1989; 44: 6-12.

263. Verstraeten A, Demedts M, Verwilghen J, et al. Predictive value of bronchoalveolar lavage in pulmonary sarcoidosis. Chest 1990; 98: 560-567.

264. Foley NM, Coral AP, Tung K, Hudspith BN, James DG, Johnson NMI. Bronchoalveolar lavage cell counts as predictor of short term outcome in pulmonary sarcoidosis. Thorax 1989; 44: 732-738.

265. Lin YH, Haslam PL, Turner-Warwick M. Chronic pulmonary sarcoidosis: relationship between lung lavage cell counts, chest radiograph, and results of standard lung function tests. Thorax 1985; 40: 501-507.

266. Hollinger WM, Staton GW, Fajman WA, Gilman MJ,
Pine JR, Check LJ. Prediction of therapeutic response in steroid-treated pulmonary sarcoidosis. Am Rev Respir Dis 1985; 132: 65-69.

267. Buchalter S, App W, Jackson L, Chandler D, Jackson R, Fulmer J. Bronchoalveolar lavage cell analysis in sarcoidosis. A comparison of lymphocyte counts and clinical course. Ann NY Acad Sci 1986; 465: 678-684.

268. Lavoilette M, La Forge J, Tennina S, Boulet L. Prognostic value of lavage lymphocyte count in recently diagnosed pulmonary sarcoidosis. Chest 1991; 100: 380-384.

269. Pueringer R, Schwartz D, Dayton C, Gilbert S, Hunninghake $\mathrm{G}$. The relationship between alveolar macrophage TNF, IL-1, and $\mathrm{PGE}_{2}$ release, alveolitis, and disease severity in sarcoidosis. Chest 1993; 103: 832-838.

270. Ainslie GM, Poulter LW, du Bois RM. Relation between immunocytological features of bronchoalveolar lavage fluid and clinical indices in sarcoidosis. Thorax 1989; 44: 501-509.

271. Prior C, Barbee RA, Evans PM, et al. Lavage versus serum measurement of lysozyme, angiotensin converting enzyme and other inflammatory markers in sarcoidosis. Eur Respir J 1990; 3: 1146-1154.

272. Huber C, Batchelor JR, Fuchs D, et al. Immune responseassociated production of neopterin: release from macrophages primarily under control of interferon-gamma. $J$ Exp Med 1984; 160: 310-316.

273. Eklund A, Blaschke E. Elevated serum neopterin in sarcoidosis. Lung 1986; 164: 325-332.

274. Prior C, Frank A, Fuchs D, et al. Urinary neopterin excretion in pulmonary sarcoidosis: correlation to clinical course of disease. Clin Chim Acta 1988; 177: 211-220.

275. Homolka J, Lorenz J, Zuchhold HD, Müller-Quernheim $\mathrm{J}$. Evaluation of soluble CD14 and serum neopterin as serum parameters of inflammatory activity of pulmonary sarcoidosis. Clin Invest 1992; 70: 909-916.

276. Meliconi R, Lalli E, Borzi R, et al. Idiopathic pulmonary fibrosis: can cell mediated immunity markers predict clinical outcome. Thorax 1990; 45: 536-540.

277. Taylor A. Serum adenosine deaminase activity is increased in sarcoidosis. Clin Chem 1984; 30: 499-500.

278. Lorenz J, Wetzel E, Müller-Quernheim J, Ferlinz R. Adenosin deaminase: a novel serum marker of disease activity in sarcoidosis. Am Rev Respir Dis 1994; 149: A609.

279. Hol BEA, Hintzen RQ, van Lier RAW, Alberts C, Out TA, Jansen HM. Soluble and cellular markers of T cell activation in patients with pulmonary sarcoidosis. Am Rev Respir Dis 1993; 148: 643-649.

280. Semenzato G, Cipriani A, Trentin L, et al. High serum levels of soluble interleukin-2 receptors in sarcoidosis. Sarcoidosis 1987; 4: 25-27.

281. Lawrence EC, Brousseau KP, Berger MB, Kurman CC, Marcon L, Nelson DL. Elevated concentration of soluble interleukin-2 receptors in serum samples and bronchoalveolar fluids in active sarcoidosis. Am Rev Respir Dis 1988; 137: 759-764.

282. Ina Y, Takada K, Sato T, Yamamoto M, Noda M, Morishita M. Soluble interleukin 2 receptor in patients with sarcoidosis. Possible origin. Chest 1992; 102: 11121133.

283. Pforte A, Brunner A, Gais P, et al. Concomitant modulation of serum-soluble interleukin-2 receptor and alveolar macrophage interleukin-2 receptor in sarcoidosis. Am Rev Respir Dis 1993; 147: 717-722.

284. DeRemee R. The present status of treatment of pulmonary sarcoidosis: a house divided. Chest 1977; 71: 388-393.

285. Israel H, Fouts D, Beggs R. A controlled trial of prednisone treatment of sarcoidosis. Am Rev Respir Dis 1973; 
107: 609-614.

286. Zaki MH, Lyons HA, Leilop L, Huang CT. Corticosteroid therapy in sarcoidosis. A five-year, controlled follow-up study. N Y State J Med 1987; 87: 496-499.

287. Gibson G, Prescott R, Muers M, et al. British Thoracic Society sarcoidosis study: effects of long term corticosteroid treatment. Thorax 1996; 51: 238-247.

288. Lynch JPr, McCune WJ. Immunosuppressive and cytotoxic pharmacotherapy for pulmonary disorders. Am J Respir Crit Care Med 1997; 155: 395-420.

289. Lower EE, Baughman RP. Prolonged use of methotrexate for sarcoidosis. Arch Intern Med 1995; 155: 846-851.

290. Wyser CP, van Schalkwyk EM, Alheit B, Bardin PG, Joubert JR. Treatment of progressive pulmonary sarcoidosis with cyclosporin A. A randomized controlled trial. Am J Respir Crit Care Med 1997; 156: 1371-1376.

291. Lynch JPr. Pulmonary sarcoidosis: current concepts and controversies. Compr Ther 1997; 23: 197-210.

292. Baughman RP, Lower EE. Steroid-sparing alternative treatments for sarcoidosis. Clin Chest Med 1997; 18: 853-864.

293. Martinet Y, Pinkston P, Saltini C, Spurzem J, MüllerQuernheim J, Crystal RG. Evaluation of the in vitro and in vivo effects of cyclosporine on the T-lymphocyte alveolitis of active pulmonary sarcoidosis. Am Rev Respir Dis 1988; 138: 1242-1248.

294. Baughman RP, Lower EE. The effect of corticosteroid or methotrexate therapy on lung lymphocytes and macrophages in sarcoidosis. Am Rev Respir Dis 1990; 142: $1268-1271$.

295. Gupta M, Satyaraj E, Durdik JM, Rath S, Bal V. Differential regulation of $\mathrm{T}$ cell activation for primary versus secondary proliferative responses. J Immunol 1997; 158: 4113-4121.
296. Han J, Thompson P, Beutler B. Dexamethasone and pentoxifylline inhibit endotoxin-induced cachectin/tumor necrosis factor synthesis at separate points in the signaling pathway. J Exp Med 1990; 172: 391-394.

297. Zabel P, Wolter D, Schönharting M, Schade U. Oxpentifylline in endotoxinaemia. Lancet 1989; 334: 1474-1477.

298. Moller DR, Wysocka M, Greenlee BM, Ma X, Wahl L, Karp CL. Inhibition of human interleukin-12 production by pentoxifylline. Immunology 1997; 91: 197-203.

299. Funk J, Ernst M, Schlaak M, Zabel P. Pentoxifylline exerts synergistic immunomodulatory effects in combination with dexamethasone or cyclosporine. Int J Immunopharmacol 1995; 17: 1007-1016.

300. Zabel P, Entzian P, Dalhoff K, Schlaak M. Pentoxifylline in treatment of sarcoidosis. Am J Respir Crit Care Med 1997; 155: 1665-1669.

301. Sheskin J. Further observation with thalidomide in lepra reactions. Lepr Rev 1965; 36: 183-187.

302. Moller DR, Wysocka M, Greenlee BM, et al. Inhibition of IL-12 production by thalidomide. J Immunol 1997; 159: 5157-5161.

303. Sampaio EP, Sarno EN, Galilly R, Cohn ZA, Kaplan G. Thalidomide selectively inhibits tumor necrosis factor alpha production by stimulated human monocytes. $J$ Exp Med 1991; 173: 699-703.

304. Tavares JL, Wangoo A, Dilworth P, Marshall B, Kotecha $S$, Shaw RJ. Thalidomide reduces tumor necrosis factor- $\alpha$ production by human alveolar macrophages. Respir Med 1997; 91: 31-40.

305. Elder JT, Nair RP, Guo SW, Henseler T, Christophers E, Voorhees JJ. The genetics of psoriasis. Arch Dermatol 1994; 130: 216-224. 